\title{
Carbon monoxide climatology derived from the trajectory mapping of global MOZAIC-IAGOS data
}

\author{
Mohammed K. Osman ${ }^{1, a}$, David W. Tarasick ${ }^{1}$, Jane Liu ${ }^{2,5}$, Omid Moeini ${ }^{1}$, Valerie Thouret $^{3}$, Vitali E. Fioletov ${ }^{1}$, \\ Mark Parrington ${ }^{4}$, and Philippe Nédélec ${ }^{3}$ \\ ${ }^{1}$ Environment Canada, 4905 Dufferin Street, Downsview, ON, M3H 5T4, Canada \\ ${ }^{2}$ Department of Geography and Program in Planning, University of Toronto, 100 St. George Street, Toronto, Ontario, \\ M5S 3G3, Canada \\ ${ }^{3}$ Laboratoire d'Aérologie, UMR5560, CNRS and Université de Toulouse, Toulouse, France \\ ${ }^{4}$ European Centre for Medium-Range Weather Forecasts, Shinfield Park, Reading, RG2 9AX, UK \\ ${ }^{5}$ School of Atmospheric Sciences, Nanjing University, Nanjing, 210023, China \\ ${ }^{a}$ current affiliation: Cooperative Institute for Mesoscale Meteorological Studies, The University of Oklahoma, and \\ NOAA/National Severe Storms Laboratory, Norman, Oklahoma, USA
}

Correspondence to: Mohammed K. Osman (mohammed.osman@noaa.gov)

Received: 17 September 2015 - Published in Atmos. Chem. Phys. Discuss.: 2 November 2015

Revised: 4 May 2016 - Accepted: 11 July 2016 - Published: 12 August 2016

\begin{abstract}
A three-dimensional gridded climatology of carbon monoxide $(\mathrm{CO})$ has been developed by trajectory mapping of global MOZAIC-IAGOS in situ measurements from commercial aircraft data. CO measurements made during aircraft ascent and descent, comprising nearly 41200 profiles at 148 airports worldwide from December 2001 to December 2012, are used. Forward and backward trajectories are calculated from meteorological reanalysis data in order to map the $\mathrm{CO}$ measurements to other locations and so to fill in the spatial domain. This domain-filling technique employs 15800000 calculated trajectories to map otherwise sparse MOZAIC-IAGOS data into a quasi-global field. The resulting trajectory-mapped $\mathrm{CO}$ data set is archived monthly from 2001 to 2012 on a grid of $5^{\circ}$ longitude $\times 5^{\circ}$ latitude $\times 1 \mathrm{~km}$ altitude, from the surface to $14 \mathrm{~km}$ altitude.

The mapping product has been carefully evaluated, firstly by comparing maps constructed using only forward trajectories and using only backward trajectories. The two methods show similar global CO distribution patterns. The magnitude of their differences is most commonly $10 \%$ or less and found to be less than $30 \%$ for almost all cases. Secondly, the method has been validated by comparing profiles for individual airports with those produced by the mapping method when data from that site are excluded. While there are larger differences below $2 \mathrm{~km}$, the two methods agree
\end{abstract}

very well between 2 and $10 \mathrm{~km}$ with the magnitude of biases within $20 \%$. Finally, the mapping product is compared with global MOZAIC-IAGOS cruise-level data, which were not included in the trajectory-mapped data set, and with independent data from the NOAA aircraft flask sampling program. The trajectory-mapped MOZAIC-IAGOS CO values show generally good agreement with both independent data sets.

Maps are also compared with version 6 data from the Measurements Of Pollution In The Troposphere (MOPITT) satellite instrument. Both data sets clearly show major regional $\mathrm{CO}$ sources such as biomass burning in Central and southern Africa and anthropogenic emissions in eastern China. While the maps show similar features and patterns, and relative biases are small in the lowermost troposphere, we find differences of $\sim 20 \%$ in $\mathrm{CO}$ volume mixing ratios between 500 and $300 \mathrm{hPa}$. These upper-tropospheric biases are not related to the mapping procedure, as almost identical differences are found with the original in situ MOZAIC-IAGOS data. The total CO trajectory-mapped MOZAIC-IAGOS column is also higher than the MOPITT CO total column by $12-16 \%$.

The data set shows the seasonal CO cycle over different latitude bands and altitude ranges as well as long-term trends over different latitude bands. We observe a decline in $\mathrm{CO}$ 
over the northern hemispheric extratropics and the tropics consistent with that reported by previous studies using other data sources.

We anticipate use of the trajectory-mapped MOZAICIAGOS CO data set as an a priori climatology for satellite retrieval and for air quality model validation and initialization.

\section{Introduction}

Atmospheric carbon monoxide (CO) is an important global air pollutant and trace gas. Due to its relatively long lifetime of 1-4 months (Hubler et al., 1992; Law and Pyle, 1993), it is an ideal tracer for long-range atmospheric transport (Logan et al., 1981; Lelieveld et al., 2001; Shindell et al., 2006). Moreover, in the tropics, it is an important tracer of upward transport during convective events (e.g., Pommrich et al., 2014). Consequently, it has been employed to facilitate interpretations of chemical measurements (Jaffe et al., 1996; Parrish et al., 1991, 1998; Wang et al., 1996, 1997) and in validating chemical transport models (Carmichael et al., 2003; Liu et al., 2003; Tan et al., 2004; Wang et al., 2004). The main sources of atmospheric $\mathrm{CO}$ are relatively well understood (Galanter et al., 2000; Granier et al., 2011; Holloway et al., 2000); however, the magnitude of individual sources and their seasonal variability, especially of biomass burning, are not well quantified. Stein et al. (2014) also reported that models are also generally biased low due to either an underestimation of CO sources or an overestimation of its sinks. There are differences in the emission densities of anthropogenic and natural sources, despite the fact that the anthropogenic and natural sources are of similar magnitude on a global scale (Granier et al., 2011; Logan et al., 1981). The anthropogenic sources are primarily associated with large industrial centers or major biomass burning regions while the natural sources, such as oxidation of methane $\left(\mathrm{CH}_{4}\right)$ and non-methane hydrocarbons (NMHCs), are much more diffuse. This makes CO a good atmospheric tracer gas for anthropogenic emissions as its lifetime allows it to be used as an indicator of how large-scale atmospheric transport redistributes pollutants on a global scale.

CO plays a vital role in the chemistry of the atmosphere. This significance mainly comes from the influence of $\mathrm{CO}$ on the concentrations and distributions of the atmospheric oxidants, ozone $\left(\mathrm{O}_{3}\right)$, the hydroperoxy $\left(\mathrm{HO}_{2}\right)$, and hydroxyl radicals $(\mathrm{OH})$ (e.g. Novelli et al., 1994, 1998). Reaction (R1) between $\mathrm{CO}$ and $\mathrm{OH}$ represents $90-95 \%$ of the $\mathrm{CO}$ sink (Logan et al., 1981) and about $75 \%$ of the removal of $\mathrm{OH}$ (Thompson, 1992) in the troposphere:
$\mathrm{CO}+\mathrm{OH} \rightarrow \mathrm{CO}_{2}+\mathrm{H}$,

$\mathrm{H}+\mathrm{O}_{2} \rightarrow \mathrm{HO}_{2}+\mathrm{M}$.

In areas with sufficient $\mathrm{NO}_{x}\left(=\mathrm{NO}+\mathrm{NO}_{2}\right), \mathrm{HO}_{2}$ formed in Reaction (R2) leads to photochemical Reactions (R3)(R5), which bring about net $\mathrm{O}_{3}$ production. In urban areas and regions of biomass burning, large amounts of these $\mathrm{O}_{3}$ precursors will be produced, and $\mathrm{O}_{3}$ can be formed in, and downwind of, the source region (Crutzen, 1973; Fishman and Seiler, 1983):

$\mathrm{HO}_{2}+\mathrm{NO} \rightarrow \mathrm{OH}+\mathrm{NO}_{2}$,

$\mathrm{NO}_{2}+h v \rightarrow \mathrm{NO}+\mathrm{O}(<425 \mathrm{~nm})$,

$\mathrm{O}_{2}+\mathrm{O}+\mathrm{M} \rightarrow \mathrm{O}_{3}$.

$\mathrm{O}_{3}$ is associated with respiratory problems and decreased crop yields (e.g., McKee, 1993; Chameides et al., 1994). Since $\mathrm{CO}$ and $\mathrm{OH}$ are principal reaction partners, $\mathrm{CO}$ concentrations in the atmosphere have important climatological implications. $\mathrm{OH}$ is also responsible for the removal of greenhouse gases such as $\mathrm{CH}_{4}$, as well as other volatile organic compounds in the atmosphere. Via these interactions with $\mathrm{OH}, \mathrm{O}_{3}$, and $\mathrm{CH}_{4}, \mathrm{CO}$ has an indirect radiative forcing of about $0.25 \mathrm{~W} \mathrm{~m}^{-2}$ (IPCC AR5, 2013).

Global atmospheric chemistry models require accurate $\mathrm{CO}$ concentrations on a global scale in order to define spatial and temporal variations of atmospheric oxidants and $\mathrm{CO}$. For this reason measurements of $\mathrm{CO}$ are made by different kinds of remote sensing and in situ instruments, in ground-based networks, aircraft programmes, and from space (Novelli et al., 1994, 1998; Rinsland and Levine, 1985; Zander et al., 1989; Brook et al., 2014; Reichle Jr. et al., 1990, 1999; Worden et al., 2013; Petzold et al., 2015). Long-range atmospheric transport redistributes $\mathrm{CO}$ widely due to its relatively long lifetime. Typical tropospheric background $\mathrm{CO}$ levels range between 50 and $120 \mathrm{ppbv}$ (WHO, 2000). Mixing ratios much higher than $250 \mathrm{ppb}$ have been observed in the upper troposphere over Asia (Nédélec et al., 2005) or over the Pacific (Clark et al., 2015) in biomass burning plumes. $\mathrm{CO}$ values as high as 1800 ppbv have been reported over Beijing (Zbinden et al., 2013)

Early studies of ground-based observations showed increasing trends in global CO before 1980 (Khalil and Rasmussen, 1988; Rinsland and Levine, 1985; Zander et al., 1989), followed by a modest decline in the 1990s (Novelli et al., 1994, 2003; Khalil and Rasmussen, 1994). More recently satellite observations have shown that the decline has continued: Worden et al. (2013) report a global trend from 2000 to 2011 of $\sim 10 \%$ per decade on column CO in the Northern Hemisphere (NH). Petetin et al. (2015) show a similar decrease of about 2 ppb per year over Frankfurt throughout the troposphere from 2002 to 2012. The decrease is at least partly due to a decrease in global anthropogenic $\mathrm{CO}$ emissions (Granier et al., 2011). 
In-service Aircraft for a Global Observing System (IAGOS) and its predecessor Measurement of Ozone and water vapor by Airbus In-service airCraft (MOZAIC) have been making automatic and regular measurements of $\mathrm{O}_{3}$, water vapor, and standard meteorological parameters onboard longrange commercial Airbus A340 aircraft since August 1994 (Marenco et al., 1998; Petzold et al., 2015). Measurements of CO (Nédélec et al., 2003) and $\mathrm{NO}_{y}$ (the sum of $\mathrm{NO}_{x}$ plus its atmospheric oxidation products) (Volz-Thomas et al., 2005) were added in late 2001. The MOZAIC database currently contains data from more than 41200 vertical profiles of $\mathrm{CO}$, measured during takeoff and landing from 148 airports around the world. MOZAIC measurements show the general features of the atmospheric $\mathrm{CO}$ distribution (Zbinden et al., 2013; Petzold et al., 2015, and references therein), capturing major regional features (e.g., strong $\mathrm{CO}$ emissions from biomass burning or anthropogenic sources).

The objective of this paper is to present a threedimensional (i.e., latitude, longitude, altitude) gridded climatology of carbon monoxide that has been developed by trajectory mapping of global MOZAIC-IAGOS CO data from 2001 to 2012. We employ a domain-filling technique, using approximately 15800000 calculated trajectories to map otherwise sparse MOZAIC-IAGOS CO data into a global field.

This is a technique that has been used successfully with tropospheric and stratospheric ozonesonde data (G. Liu et al., 2013; J. Liu et al., 2013). Stohl et al. (2001) used trajectory statistics to extend one year of MOZAIC $\mathrm{O}_{3}$ measurements into a four-season $\mathrm{O}_{3}$ climatology at $10^{\circ}$ longitude by $6^{\circ}$ latitude and three vertical heights. Tarasick et al. (2010) developed high-resolution $\left(1^{\circ} \times 1^{\circ} \times 1 \mathrm{~km}\right.$ in latitude, longitude, and altitude) tropospheric $\mathrm{O}_{3}$ fields for North America from ozonesonde data from the INTEX (Intercontinental Transport Experiment) and ARCTAS (Arctic Research of the Composition of the Troposphere from Aircraft and Satellites) campaigns, and this was extended to global tropospheric ozonesonde data by G. Liu et al. (2013). It is possible to apply this technique to $\mathrm{CO}$ because the lifetime of $\mathrm{CO}$ in the troposphere, as noted above, is generally of the order of weeks or months. This physically based method, using the reanalysis meteorological data from the National Centers for Environmental Prediction/National Center for Atmospheric Research (NCEP/NCAR) (Kalnay et al., 1996) to, in effect, interpolate data based on knowledge of atmospheric transport, offers obvious advantages over typical statistical interpolation methods.

\section{Measurements of $\mathrm{CO}$}

\subsection{MOZAIC-IAGOS}

$\mathrm{CO}$ measurements were made by an improved version of a commercial model 48CTL CO Analyzer from Thermo Environmental Instruments employing the gas filter correlation

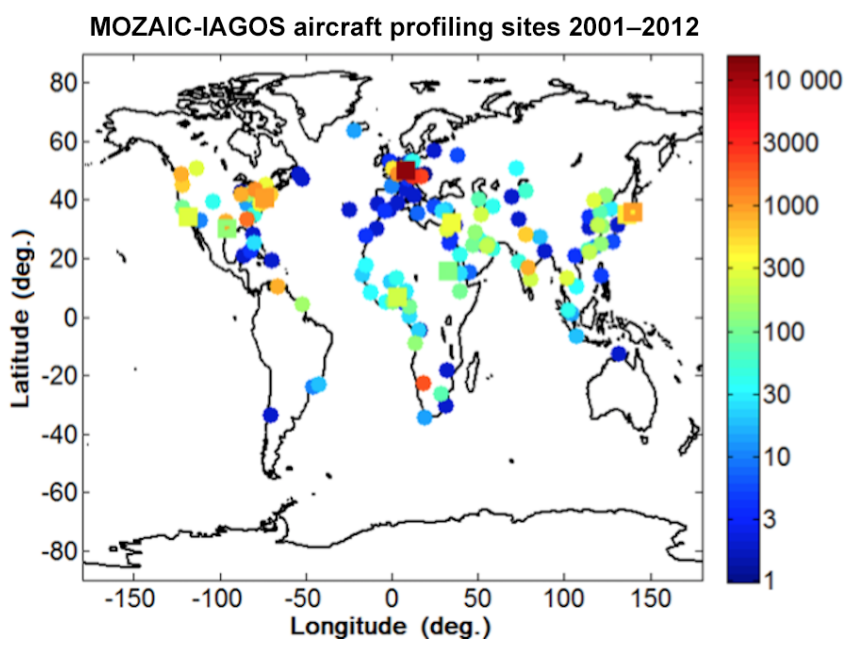

Figure 1. Airports visited by MOZAIC-IAGOS aircraft from 2001 to 2012. The color bar indicates the number of profiles available from each airport. The squares show the locations of the selected airports used for the validation in this study.

technique. The model 48CTL is based on the principle that $\mathrm{CO}$ absorbs infrared radiation at a wavelength of $4.67 \mu \mathrm{m}$. For $30 \mathrm{~s}$ integration time (the response time of the instrument) the precision achieved is $5 \mathrm{ppb}$ (noise) or $5 \%$ (calibration) $\mathrm{CO}$, with minimum detection limit of $10 \mathrm{ppb}$. The analyzer samples at a horizontal resolution of about $7 \mathrm{~km}$ (since the maximum cruise speed of the Airbus A340 aircraft is nearly $250 \mathrm{~m} \mathrm{~s}^{-1}$ ) and the vertical resolution during ascents and descents is nearly $300 \mathrm{~m}$. Nédélec et al. (2003 for MOZAIC, 2015 for IAGOS) give detailed descriptions of the $\mathrm{CO}$ analyzer, measurement technique, instrument validation, and quality testing.

The airports visited by aircraft equipped with MOZAICIAGOS instrumentation are shown in Fig. 1. Further details are available at http://www.iagos.fr.

The sampled data from these airports are unevenly distributed spatially, and also temporally because the frequency of visits to airports by aircraft that take part in MOZAICIAGOS varies considerably depending on commercial airlines' operational constraints. Thus at Frankfurt, Germany, we find 12324 CO profiles while from Dammam, Saudi Arabia, we have only 2 during the period 2001-2012. The trajectory-mapping method is valuable for filling the sparse and variable spatial domain.

\subsection{MOPITT}

MOPITT is a nadir-viewing gas correlation radiometer which provides global atmospheric profiles of $\mathrm{CO}$ volume mixing ratio (VMR) and CO total column values using near-infrared radiation (NIR) at $2.3 \mu \mathrm{m}$ and thermal-infrared radiation (TIR) at $4.7 \mu \mathrm{m}$ (Drummond and Mand, 1996). CO columns and profiles are retrieved from the infrared emission channels 
$(4.6 \mu \mathrm{m})$ for all cloud-free scenes. The MOPITT measurement technique relies on a temperature gradient within the atmosphere, leading to a retrieval dependence on surface temperature, and little sensitivity to $\mathrm{CO}$ in the boundary layer. The retrieval uses a priori profiles that vary geographically and temporally. MOPITT-derived CO VMR profiles reflect the vertical sensitivity of the measurement as defined by the retrieval averaging kernel (e.g. Fig. 3) and a priori profile. In this study, we have used Level 3, Version 6 monthly CO mixing ratio profile data, reported on 10 pressure levels, as well as CO total column. Nighttime CO observations of MOPITT have not been validated and appear subject to larger bias (Heald et al., 2004). Hence, we use the daytime data for comparison. MOPITT data are publicly available at the NASA Langley Research Center Atmospheric Science Data Center (https://eosweb.larc.nasa.gov/project/mopitt/mopitt_table).

MOPITT was launched in 1999 into sun-synchronous polar orbit with a 10:30 local time (LT) northward or southward equatorial crossover time. The instrument field of view is $22 \times 22 \mathrm{~km}^{2}$. Cross-track scanning with a $612 \mathrm{~km}$ swath provides near complete coverage of the surface of the Earth approximately every 3 days. MOPITT retrievals have gone through intensive validation against in situ measurements from aircraft on a regular basis since the start of the mission (Worden et al., 2010; Deeter et al., 2012, 2013, 2014; Emmons et al., 2004, 2007, 2009; Jacob et al., 2003). MOPITT CO retrievals have also been validated by comparing to ground-based and TES (Tropospheric Emission Spectrometer) satellite measurements (Jacob et al., 2003; Luo et al., 2007). Deeter et al. (2014) employ the MOPITT L3 V6 product and show biases to vary from $-5.2 \%$ at $400 \mathrm{hPa}$ to $8.9 \%$ at the surface. Previous studies used earlier versions of the MOPITT product.

\subsection{Trajectory calculation and global CO mapping via HYSPLIT (HYbrid Single-Particle Lagrangian Integrated Trajectory)}

For each CO profile of the MOZAIC-IAGOS data set presented here, the mean CO VMR was calculated for $1 \mathrm{~km}$ intervals from sea level up to $12 \mathrm{~km}$ (the maximum altitude of the aircraft). Cruise data were not used. The HYSPLIT model version 4.9 (Draxler and Hess, 1998; Draxler, 1999) was employed to calculate trajectories for each level of each profile. The exact location of the aircraft was used to start the trajectories. HYSPLIT, publicly accessible at http: //ready.arl.noaa.gov/HYSPLIT.php, uses the reanalysis meteorological wind fields from NCEP/NCAR (Kalnay et al., 1996) as an input to describe the transport of CO in the atmosphere. The reanalysis data are available from 1948 until the present. Both forward and backward trajectories for 4 days at $6 \mathrm{~h}$ intervals (32 positions for each level) were calculated for $41200 \mathrm{CO}$ profiles, and the mean CO mixing ratios from each level (i.e., tropospheric and lower stratospheric air masses) of each profile were assigned to the corresponding trajectory positions along the forward and backward paths. Trajectories only move upward and downward with the meteorological vertical velocity fields since the HYSPLIT kinematic trajectory model employs vertical motions supplied with the NCEP reanalysis meteorological data set. Numerous studies show that the choice of vertical wind velocity has significant impact on the transport of tracers (e.g., Schoeberl et al., 2003; Ploeger et al., 2010, 2012). Kinematic models show excessive dispersion for tracers with strong gradients (e.g., $\mathrm{O}_{3}$ in the vicinity of the tropopause), particularly for trajectories of 7 days or more. Here trajectories were limited to a maximum of 4 days in length. Moreover, unlike $\mathrm{O}_{3}, \mathrm{CO}$ does not have a strong vertical gradient in the upper troposphere. Trajectories that reach the ground continue at the surface where trajectory robustness is more uncertain. Trajectories that reach the top height of the model $(20000 \mathrm{~m}$ above sea level) terminate. Although HYSPLIT is capable of generating a trajectory every hour (i.e., 24 trajectories per day), the typical maximum frequency of $\mathrm{CO}$ measurements is around two profiles per day (with the exception of Frankfurt, where we can get up to six profiles per day). In this version, no attempt was made to identify individual CO sources; however, the climatology could in principle be refined by excluding back trajectories from sources identified via emission inventories. We note, however, that if major anthropogenic sources were a significant source of error, we would see differences between the $\mathrm{CO}$ mapping produced using only backward and only forward trajectories (see Sect. 3.1).

This mapping implicitly assumes that CO chemistry may be neglected over a timescale of 4 days. Except near major sources, this assumption should be valid, as the lifetime of $\mathrm{CO}$ is much longer. However, trajectories have significant errors over such timescales. Stohl (1998), in a comprehensive review, quotes typical errors of about $100-200 \mathrm{~km} \mathrm{day}^{-1}$ in the troposphere. This can be combined with an estimate of the correlation length in the troposphere to yield an estimate for the information value of a mapped measurement. Liu et al. (2009) find that $\mathrm{O}_{3}$ measurements in the troposphere correlate with an exponential dependence of approximately $e^{-(r / R)^{1.5}}$, where $r$ is distance and $R$ is a correlation length of $500-1000 \mathrm{~km}$ in the troposphere and $1000-2000 \mathrm{~km}$ in the stratosphere. As the CO lifetime is even longer than the ozone lifetime, the correlation length for $\mathrm{CO}$ should be at least as large. Therefore, the trajectory-mapped data were binned at intervals of $5^{\circ}$ latitude and $5^{\circ}$ longitude, at every $1 \mathrm{~km}$ altitude, and averaged with a weighting, $w$, assigned according to the formula:

$w=e^{-(150 t / R)^{1.5}}$,

where $R$ is the correlation length (taken as $700 \mathrm{~km}$ in the troposphere and $1500 \mathrm{~km}$ in the stratosphere), and $t$ is the age of the trajectory in days.

The trajectory mapping greatly spreads out the in situ $\mathrm{CO}$ information along the trajectory paths, increasing the spa- 
tial domain to include much of the globe. Two different vertical coordinate systems were utilized for the binning, and hence the maps were generated for elevations above sea level and above ground level. Data are available publicly at ftp: //es-ee.tor.ec.gc.ca/pub/ftpdt/MOZAIC_output_CO/. In this work, we present global $\mathrm{CO}$ maps generated for elevations above sea level. Global maps of monthly, annual, seasonal, and decadal means are presented, for each altitude, from 2001 to 2012.

\subsection{Distribution of data and uncertainties associated with trajectory mapping}

Figure 2 shows typical standard errors of the mapping product and the number of samples per grid cell, for typical monthly, annual, and decadal maps at $4.5 \mathrm{~km}$ altitude above sea level. Similar figures for other levels are included with the climatology on the FTP site. As can be seen, the largest number of samples per grid cell and the lowest standard errors are found over North America and Europe as there are more frequent MOZAIC-IAGOS aircraft flights in this region. Higher standard errors are found at $\mathrm{NH}$ high latitudes and much of the Southern Hemisphere (SH), where airports visits by MOZAIC-IAGOS-equipped aircraft are much fewer. The standard error is computed using all data points found inside a grid cell. This is probably biased low, since some grid cells may contain more than one value from a particular trajectory. This bias is likely not more than a factor of 2, based on typical trajectory lengths. These maps present a visual interpretation that distinguishes regions where the CO climatology is "statistically robust" (for example, North America and Europe) from those regions where the uncertainty is larger. The average number of samples is approximately 20, 90, and 140 per grid cell for the monthly, annual, and decadal maps, and this number does not vary greatly among layers. The average standard error is generally between 3 and $4 \%$ of the mean at $4.5 \mathrm{~km}$ for all three averaging periods. The monthly mean shows the highest error and the lowest number of samples per grid cell.

\subsection{MOZAIC-IAGOS Comparison with MOPITT}

When comparing the MOPITT retrievals with in situ data, it is necessary to take into account the sensitivity of the retrievals to the true profiles. The method used by MOPITT to retrieve tropospheric $\mathrm{CO}$ profiles follows that of Rodgers (2000). In order to perform the most meaningful and accurate comparison, the in situ data to be compared must be transformed using the averaging kernel matrix, $\mathbf{A}$, and a priori profile, $\boldsymbol{x}_{\mathrm{a}}$, as shown by Eq. (2). A "retrieved" comparison profile, $\boldsymbol{x}_{\text {ret }}$, is calculated by using the in situ profile, $\boldsymbol{x}$, as the "true" profile in Eq. (2), which is interpolated to the lower resolution of MOPITT. As described by Emmons et al. (2004), the in situ profile ( $\boldsymbol{x}$ ) is transformed with averaging kernel matrix (A) and the a priori CO profile $\left(\boldsymbol{x}_{\mathrm{a}}\right)$ to get a
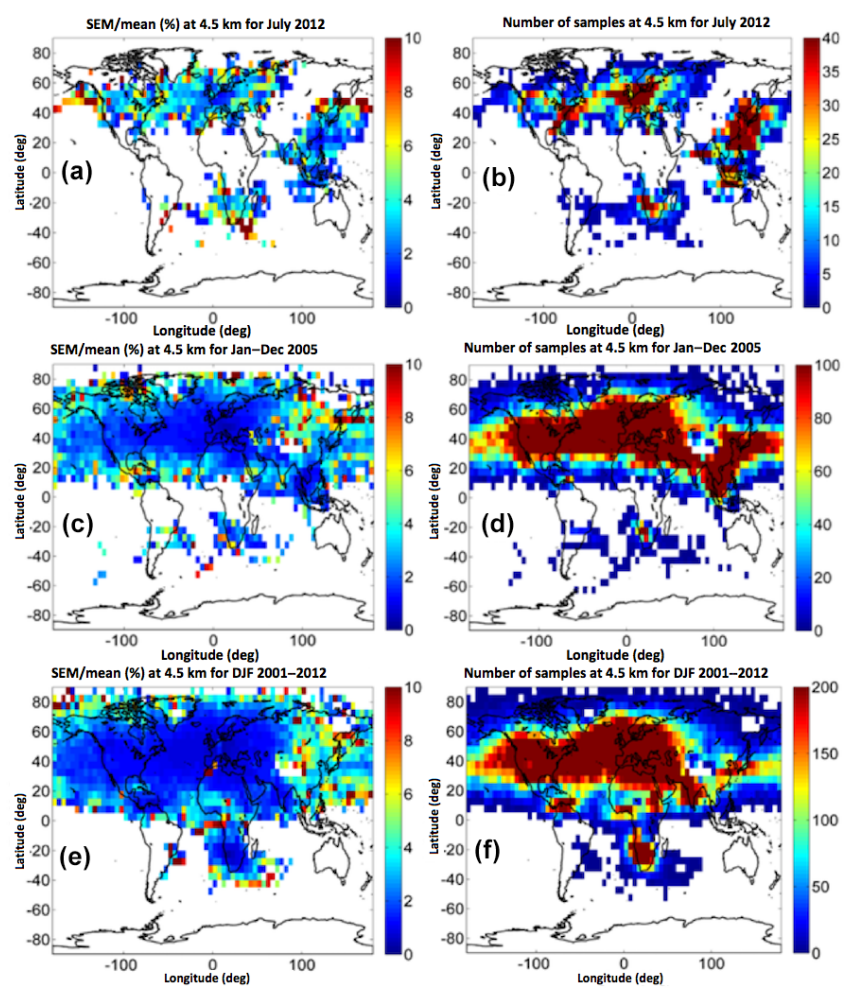

Figure 2. The standard error of the mean (left panels) and number of samples (right panels) for monthly (July 2012), annual (2005), and seasonal (DJF 2001-2012) means at $4.5 \mathrm{~km}$ altitude above sea level. The month and year shown are chosen as typical; other months and years show similar patterns. The data are binned on a $5^{\circ} \times 5^{\circ}$ latitude and longitude grid.

profile $\left(\boldsymbol{x}_{\text {ret }}\right)$, the appropriate quantity to compare with the MOPITT retrievals:

$\boldsymbol{x}_{\text {ret }}=\boldsymbol{x}_{\mathrm{a}}+\mathbf{A}\left(\boldsymbol{x}-\boldsymbol{x}_{\mathrm{a}}\right)+\varepsilon=\mathbf{A} \boldsymbol{x}+(\mathbf{I}-\mathbf{A}) \boldsymbol{x}_{\mathrm{a}}+\varepsilon$,

where $\mathbf{I}$ is the identity matrix and $\varepsilon$ is the retrieval error due to random errors in the measurement and systematic errors in the forward model (e.g., the error in the atmospheric temperature retrieval). $\boldsymbol{x}_{\text {ret }}, \boldsymbol{x}$, and $\boldsymbol{x}_{\mathrm{a}}$ are expressed in terms of the logarithm of the VMR. The averaging kernels provide the relative weighting between the true and a priori profiles and reflect the sensitivity of the retrieval to the measurement (Worden et al., 2013). They are very sensitive to the surface temperature and will be different for each point on the globe. The matrix A describes the sensitivity of the retrieved $\mathrm{CO} \log (\mathrm{VMR})$ profile to perturbations applied at each level of the "true" $\log (\mathrm{VMR})$ profile. The quantity $\boldsymbol{x}_{\text {ret }}$, the transformed in situ profile, represents the result of applying a linear transformation to the in situ profile in the same way that the remote sensing retrieval process is believed to transform the true profile. Thus, $\boldsymbol{x}_{\text {ret }}$ can be directly compared against the MOPITT-retrieved CO profile in a manner that is not affected by varying vertical resolution or a priori dependence. The vertical resolution of the retrieved profile is described 
by the shapes of the averaging kernels. Figure 3 shows that the kernels are broad except at pressure levels between 400 and $300 \mathrm{hPa}$ and exhibit a large degree of overlap. The overlap of the averaging kernels peaking in the boundary layer and those at the top of the atmosphere indicates a significant correlation for the retrieved values at these levels. Typical full-width at half maximum (FWHM) of these curves is approximately $5-8 \mathrm{~km}$. The retrieved $\mathrm{CO}$ values at both top and bottom are also influenced by $\mathrm{CO}$ at mid-levels and by the a priori $\mathrm{CO}$ profile at all pressure levels. The averaging kernels also describe the relative contributions, to the CO VMR retrieved at a given level, of the true and a priori (via $\mathbf{I}-\mathbf{A}$ ) $\mathrm{CO}$ profiles at all pressure levels (Eq. 2). Where the area under the averaging kernel is smaller, the a priori information in the retrieved CO profile is relatively larger. MOPITT CO averaging kernels exhibit variability from month to month, season to season, as well as nighttime to daytime, depending on the atmospheric temperature profile, surface pressure, and the $\mathrm{CO}$ profile itself.

The vertical coordinate of the MOZAIC-IAGOS climatology profile is in kilometers above sea level, while the MOPITT a priori profile and averaging kernels are on pressure levels in $\mathrm{hPa}$. Therefore, before applying the MOPITT averaging kernels the climatology data were interpolated using NCEP global pressure profiles that vary as a function of time (month) and latitude, to the 10 vertical pressure grid levels $(1000,900,800,700,600,500,400,300,200$, and $100 \mathrm{hPa}$ ) used by MOPITT. The interpolated profile was then convolved with the a priori profile and the averaging kernels following Eq. (2) (Emmons et al., 2004). For the atmospheric residual above the maximum MOZAIC-IAGOS profile altitude, the MOPITT a priori profiles were used.

In order to compare with these transformed $\mathrm{CO}$ profiles, the MOPITT CO profiles, averaging kernels, and a priori profiles were mapped down from the original horizontal resolution of $1^{\circ} \times 1^{\circ}$ in latitude and longitude to a reduced $5^{\circ} \times 5^{\circ}$ grid. Two examples of comparisons of trajectorymapped MOZAIC-IAGOS CO profiles with individual (reduced) $5^{\circ} \times 5^{\circ}$ MOPITT CO profiles are shown in Fig. 3 . The application of the averaging kernels to the MOZAICIAGOS CO profile results in a vertical transformation which can shift mixing ratios significantly at some levels. The averaging kernel, for example, identified as "1000" (i.e., surface) shows how changes to the true $\mathrm{CO}$ mixing ratio at all 10 retrieval levels would each contribute to a change in the retrieved value at the surface at 1000 mbar. The original trajectory-mapped MOZAIC-IAGOS climatology profile is quite different from the transformed climatology profile and the departures of the transformed $\mathrm{CO}$ mixing ratio from the true mixing ratios can be as large as $60 \mathrm{ppb}$ at some pressure levels.

$\mathrm{CO}$ total column amounts are retrieved from the MOPITT observations in addition to the profile retrievals. The retrieved CO total column $c_{\text {ret }}$ (a scalar) is related to the re-
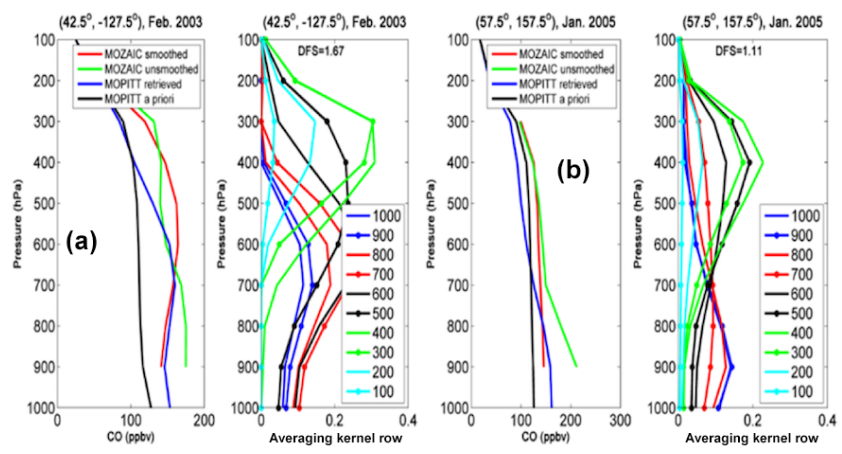

Figure 3. Examples of comparisons of monthly means of the trajectory-mapped MOZAIC-IAGOS CO profiles, with the corresponding MOPITT averaging kernels, a priori and retrievals. The left panels of each subplot show the original trajectory-mapped MOZAIC-IAGOS climatology profile (green, i.e. unsmoothed), the a priori profile, the transformed trajectory-mapped MOZAICIAGOS climatology profile (red, i.e. smoothed), and the MOPITTretrieved $\mathrm{CO}$ profile. The right panel show the mean averaging kernels, for different pressure levels, obtained by averaging all daytime averaging kernels in the $5^{\circ} \times 5^{\circ}$ latitude-longitude box centered on the coordinates indicated.

trieved profile $\boldsymbol{x}_{\text {ret }}$ (a vector) through the linear relation

$c_{\text {ret }}=\boldsymbol{t}^{\mathrm{T}} \boldsymbol{x}_{\text {ret }}$,

where $\mathrm{T}$ indicates the transpose operation and $\boldsymbol{t}$ is the total column vectors (Emmons et al., 2004; Deeter, 2002). The $\mathrm{CO}$ total column averaging kernel can be calculated from the profile averaging kernels by

$\boldsymbol{a}=\boldsymbol{t}^{\mathrm{T}} \mathbf{A}$.

The column operator simply converts the mixing ratio for each retrieval level to a partial column amount. Using the hydrostatic relation, the operator $\boldsymbol{t}$ is expressed as

$\boldsymbol{t}=2.120 \times 10^{13} \boldsymbol{\Delta} \boldsymbol{p}$.

Equation (5) is expressed in molecules $\mathrm{cm}^{-2} \mathrm{ppbv}^{-1}$ and $\Delta \boldsymbol{p}$ is the vector of the thicknesses of the retrieval pressure levels (in $\mathrm{hPa}$ ) as discussed in the MOPITT Version 5 User's Guide (Deeter, 2011).

\section{Validation}

Validation of the trajectory-mapped MOZAIC-IAGOS CO data set product has been performed by (1) comparing maps constructed using only forward trajectories against those constructed using only backward trajectories; (2) comparing profiles for individual airports against those produced by the mapping method when data from that site are excluded; (3) comparing with global MOZAIC-IAGOS cruiselevel data, which were not included in the trajectory-mapped data set; and (4) comparing with independent data from the NOAA aircraft flask sampling program. 

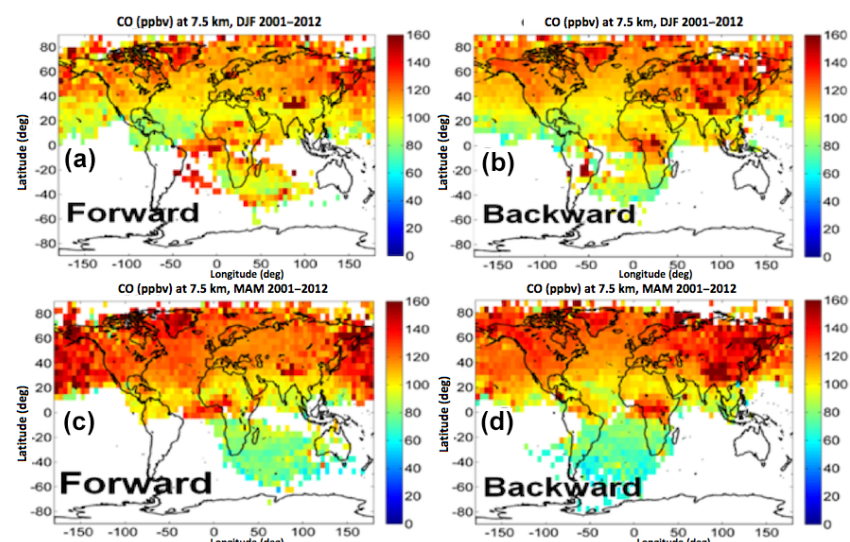

Co (pbbv) at $7.5 \mathrm{~km}, \mathrm{JA}$. 2001 201-2012
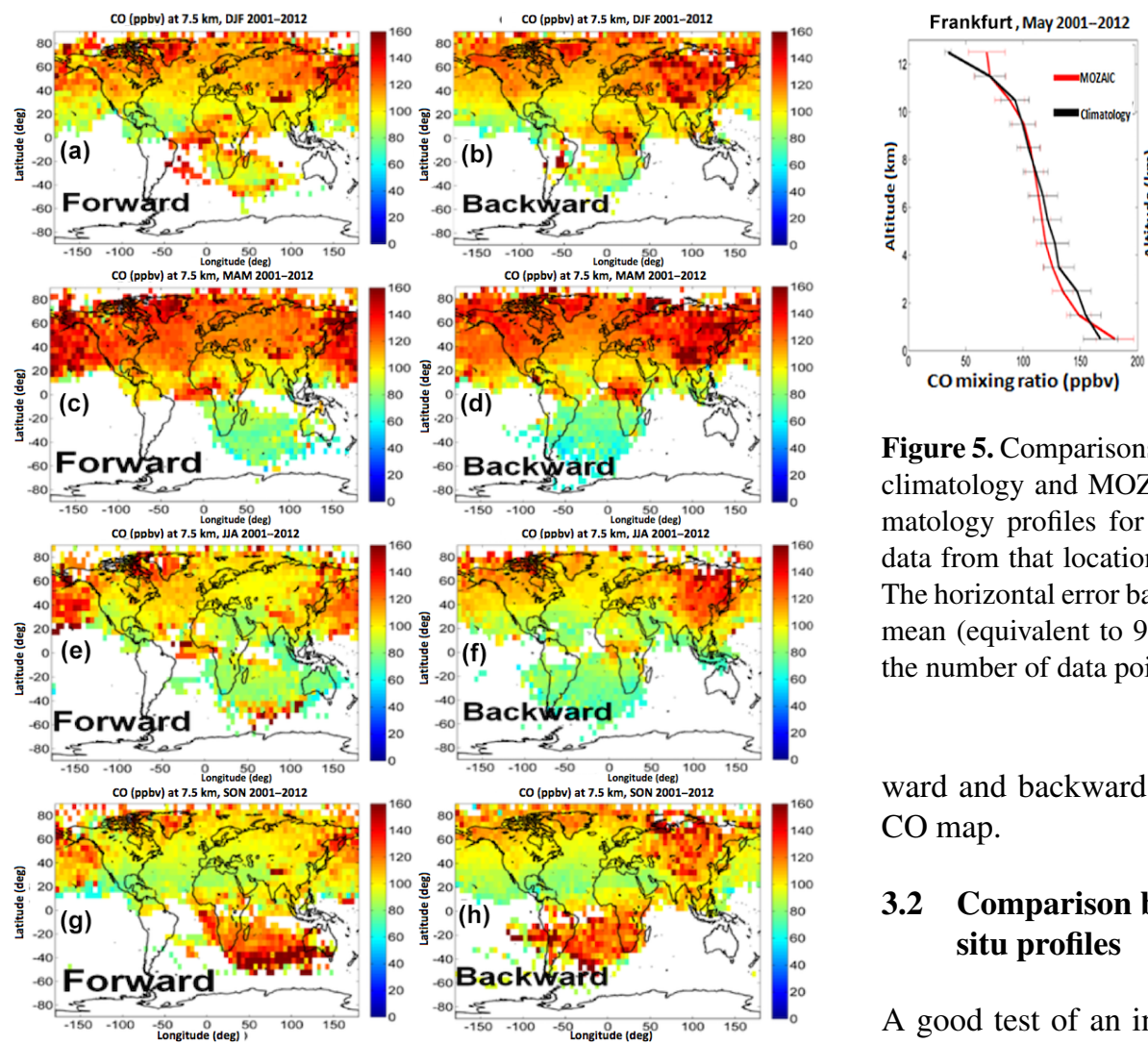
CO map.
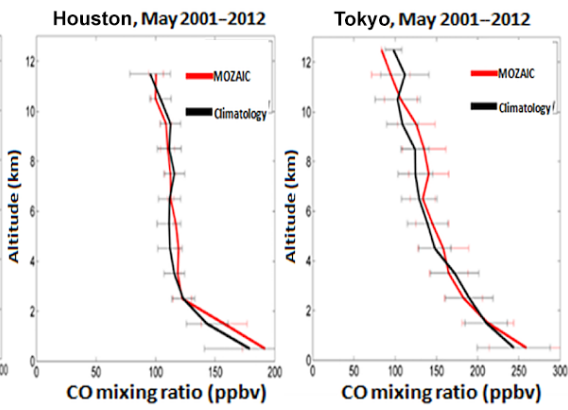

Figure 5. Comparisons of trajectory-mapped MOZAIC-IAGOS CO climatology and MOZAIC-IAGOS profiles at three sites. The climatology profiles for each location were produced by excluding data from that location but using all other MOZAIC-IAGOS data. The horizontal error bar half-length is twice the standard error of the mean (equivalent to $95 \%$ confidence limits on the averages when the number of data points is large).

ward and backward mapped values to produce an averaged

\subsection{Comparison between trajectory-mapped and in situ profiles}

A good test of an interpolation model is to examine how it performs in areas where no data are available. Figure $5 \mathrm{com}$ pares the trajectory-mapped climatology profiles at three airport sites (Frankfurt, Germany; Houston, USA; and Tokyo, Japan) with the average of the MOZAIC-IAGOS data from each of these sites for May 2001-2012. Houston and Tokyo are not as well sampled as Frankfurt (Fig. 1). The climatology profiles for each location were produced by excluding data from that location, but using all other MOZAIC-IAGOS data.

Generally, the profiles from the two methods agree very well and the agreement is especially good in the free troposphere, at altitudes between 2 and $10 \mathrm{~km}$. The magnitude of the differences for most altitudes is well under $20 \%$.

Figure 6 shows seasonally averaged differences, using this method, for a number of airports with different characteristics. The airport stations that have been selected in this validation study represent tropical and $\mathrm{NH}$ midlatitude locations that are subject to different meteorological and $\mathrm{CO}$ source conditions. Agreement is generally good in the free troposphere. There are larger differences below $2 \mathrm{~km}$ where trajectories have larger errors predominantly due to complex dispersion and turbulence in the planetary boundary layer (Stohl and Seibert, 1998). The largest differences are seen where other sources of data are distant. The smallest overall bias is seen at Frankfurt, even though the exclusion of Frankfurt data removes nearly one-third of the total number of profiles. Apparently data from nearby airports such as Munich (Germany) and Brussels (Belgium) map accurately to the Frankfurt location. The consistency of these validation tests sug- 


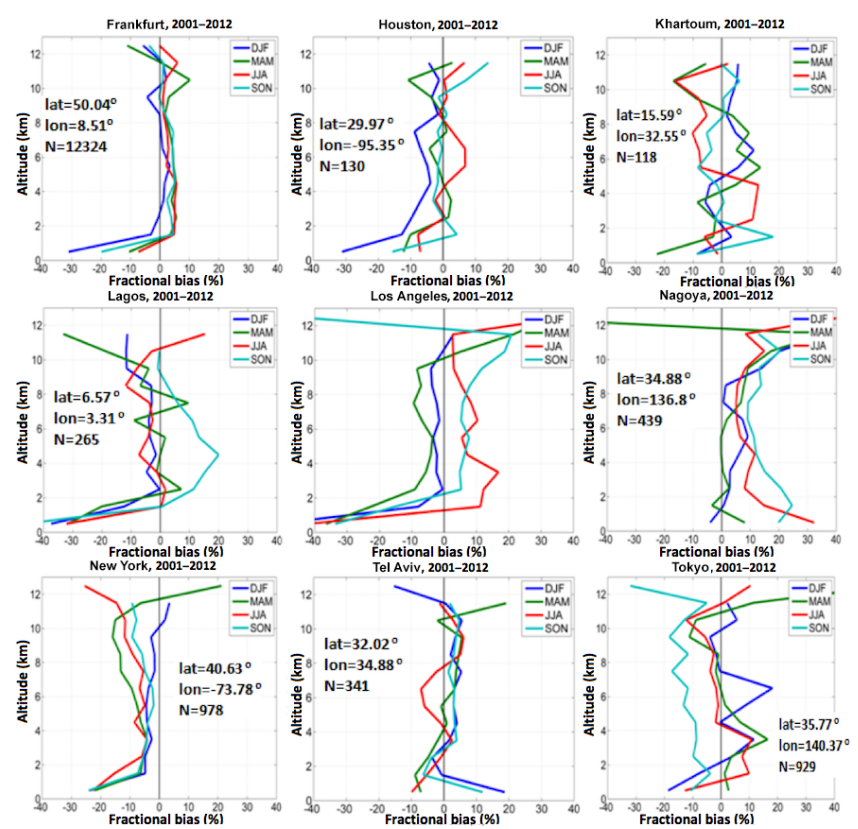

Figure 6. Seasonal mean relative biases [2(ClimMOZAIC)/(Clim+MOZAIC)], expressed in percent, between trajectory-mapped and MOZAIC-IAGOS in situ profiles for the period from 2001 to 2012. The selected airports are representative of different meteorological and source conditions across the globe. $\mathrm{N}$, lat, and lon are the number of profiles, latitude, and longitude of each airport.

gests that the trajectory-mapped data set provides a reliable picture of the tropospheric $\mathrm{CO}$ distribution.

\subsection{Comparison with the MOZAIC-IAGOS in situ for upper troposphere}

We can also compare the trajectory-mapped profile data and MOZAIC-IAGOS in situ global CO data at cruise altitudes between 8 and $12 \mathrm{~km}$. The right panels of Fig. 7 show the global seasonal mean (December-February, MarchMay, June-August, and September-November) distribution of $\mathrm{CO}$ in the upper troposphere (within $60 \mathrm{hPa}$ below the tropopause) for the period from 2003 to 2011. Elevated CO levels in the upper troposphere are generally seen over the areas where there is strong biomass burning (Central Africa, southern Africa, and South America). High CO emissions are observed over eastern China in MAM primarily due to a rise in coal use (Boden et al., 2009; Gregg et al., 2008; Tie et al., 2006) and an increasing number of vehicles (Cai and Xie, 2007).

The left panels of Fig. 7 show the trajectory-mapped climatology 2001-2012 at altitudes between 7 and $9 \mathrm{~km}$ above sea level. The trajectory-mapping yields more data over the oceans and NH high latitudes. However, both figures show high $\mathrm{CO}$ values in spring in both hemispheres and elevated $\mathrm{CO}$ levels over regions where there are strong sources. Com-
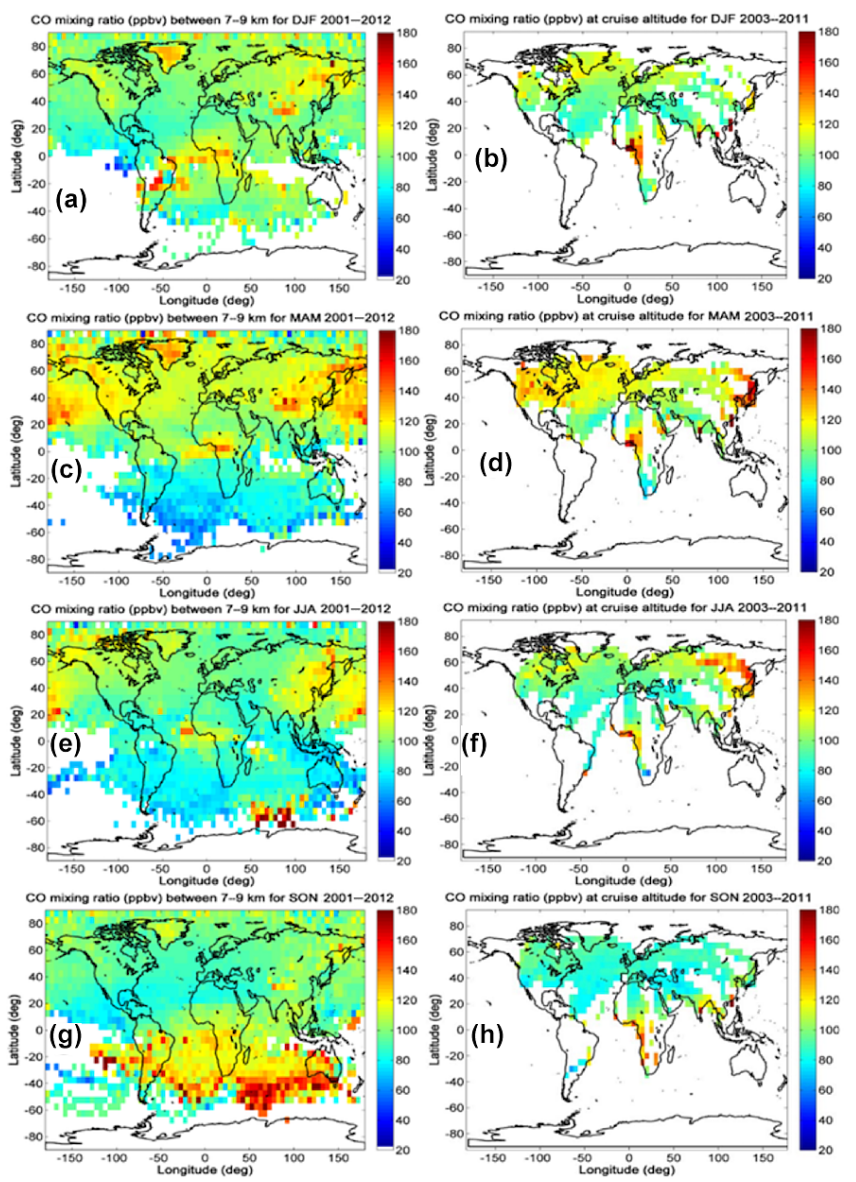

Figure 7. Global distribution of seasonal mean trajectory-mapped MOZAIC-IAGOS CO between 7 and $9 \mathrm{~km}$ altitudes above sea level for the period from 2001 to 2012. Left: MOZAIC-IAGOS trajectory. Right: MOZAIC-IAGOS cruise altitude.

parable $\mathrm{CO}$ values are noticeable from the figures over the Northern Atlantic Ocean, although the trajectory-mapped data appear high over high-elevation areas like Greenland and the Himalayas. This may be due to overcorrection of trajectories for terrain differences. Overall, the qualitative agreement between the trajectory-mapped $\mathrm{CO}$ and MOZAIC-IAGOS in situ CO cruise data appears very good, even in remote areas.

\subsection{NOAA CO vertical profiles}

The vertical in situ CO profiles acquired through NOAA's flask sampling program have been extensively utilized previously for validation of CO measurements of MOPITT (Emmons et al., 2004, 2009; Deeter et al., 2010, 2013). Typically 12-15 flask samples are utilized to derive an in situ profile and a single flask is used to sample air at a unique altitude, providing in situ measurements from near the ground up to about $300-350 \mathrm{hPa}$. The flasks are shipped to the Global Monitoring Division of NOAA's Earth System Re- 

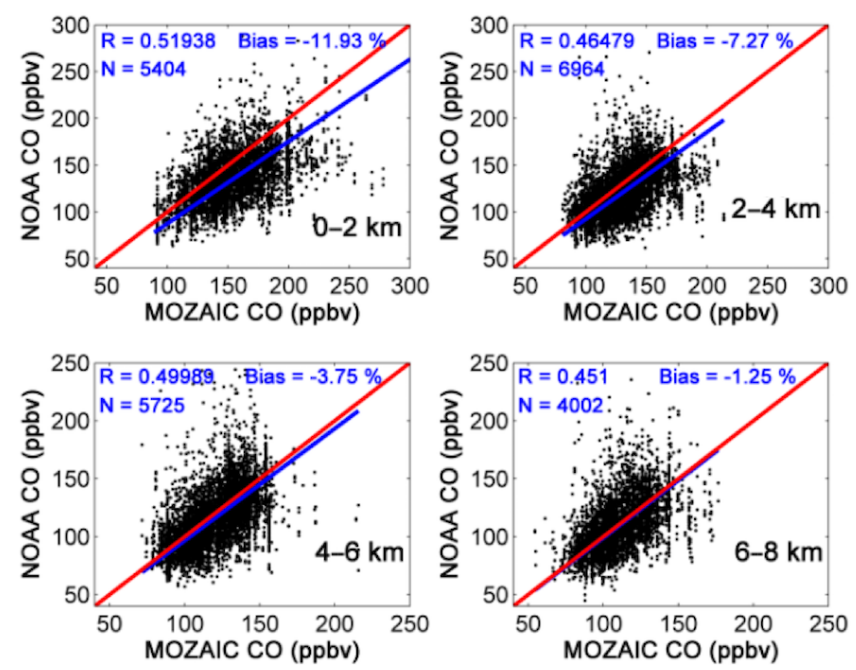

Figure 8. CO mixing ratio comparison between trajectory-derived and NOAA flask data for the period from 2001 to 2012, for four altitude ranges. Bias is calculated as the mean of the differences in percent, [2(NOAA-Clim)/(Clim+NOAA)], of all data points. The blue line is the line of best fit, the red line is the $1: 1$ line, $N$ is number of data pairs, and $R$ is the correlation coefficient. Monthly trajectory-mapped $\mathrm{CO}$ data are used for the comparison or seasonal mean values if the monthly mean value for a particular grid cell is not available.

search Laboratory (ESRL) for trace gas analysis. Details on procedures of sample collection are found in Novelli et al. (1992), Lang et al. (1992), and Conway et al. (1994).

Figure 8 shows comparisons between NOAA in situ data and the trajectory-mapped MOZAIC-IAGOS CO climatology for altitude ranges of $0-2,2-4,4-6$, and $6-8 \mathrm{~km}$. The comparison uses all available flask data (1940 profiles for the period from 2001 to 2012). NOAA CO data points are matched with the corresponding grid cell $\left(5^{\circ} \times 5^{\circ} \times 1 \mathrm{~km}\right)$ of the monthly climatology, for the same year and month. If the monthly $\mathrm{CO}$ value for a particular grid cell is missing, the seasonal mean (if it exists) of the trajectory-mapped $\mathrm{CO}$ climatology (2001-2012) is used for the comparison. Above $2 \mathrm{~km}$ agreement is fairly good, considering that the comparison is between point measurements and monthly averages over a large volume. The positive bias below $2 \mathrm{~km}$ is probably due to the effect of urban sources of $\mathrm{CO}$ since airports are located close to cities. In general, MOZAIC-IAGOS CO measurements at takeoff and landing are above background. This "airport effect" decreases rapidly as can be from the figure for higher altitudes. This decrease is because the aircraft not only ascends above the boundary layer but also samples over $150-400 \mathrm{~km}$ in distance as the aircraft ascends to, or descends from, cruise altitude.

\section{Trajectory-mapped MOZAIC-IAGOS Versus MOPITT}

This section is devoted to comparing the trajectory-mapped MOZAIC-IAGOS CO data set with the extensively validated product from the MOPITT instrument onboard the NASA Terra satellite, which has been operating continuously since March 2000 (Drummond and Mand, 1996; Edwards et al., 1999). Global comparison is made for both CO profiles and $\mathrm{CO}$ total column for different time periods.

\subsection{Comparison with MOPITT CO profiles}

As described in Sect. 2.4, in order to make a rigorous comparison with MOPITT data, the climatology profiles are first transformed using the corresponding MOPITT a priori profiles and averaging kernels via Eq. (2). Figure 3 shows examples of retrieved CO profiles $\left(\boldsymbol{x}_{\text {ret }}\right)$, together with the original climatology $(\boldsymbol{x})$ and the a priori profiles $\left(\boldsymbol{x}_{\mathrm{a}}\right)$.

When comparing MOPITT CO retrievals and the trajectory-mapped $\mathrm{CO}$ profile it is useful to keep in mind the shapes and magnitudes of the averaging kernels. For example, the generally broad and weak averaging kernels for the 100 and 1000 mbar levels indicate that a significant fraction of the information in the retrieval is from the a priori profile and from other altitudes. Figure 3 also cautions that the transformed trajectory-mapped MOZAIC-IAGOS CO is closer to both the MOPITT CO retrievals and a priori profiles when there is less information from the measurement. In the lower troposphere the MOPITT CO retrieval profile is positively biased (Deeter et al., 2014), whereas the bias is negative in the upper troposphere. In Fig. 3, we have used only the dayside retrievals from MOPITT as the dayside retrievals have the maximum information content (Deeter et al., 2004).

Figure 9 shows comparisons between MOPITT retrievals and the MOZAIC-IAGOS climatology for global CO data at pressure levels 900, 700, 500, and $300 \mathrm{hPa}$. The biases and correlations between MOPITT CO VMR and the CO climatology (after applying the averaging kernels and the a priori profiles) are indicated in each plot. There are clearly two distinct clusters of dots in Fig. 9a and b, and the high CO VMR values seen here are from the tropics, with a very small number from the NH extratropics. Recent work by Ding et al. (2015) shows the association of enhanced CO in the free troposphere with the uplifting of $\mathrm{CO}$ from biomass burning and anthropogenic sources.

MOPITT and trajectory-mapped MOZAIC-IAGOS CO climatology mixing ratios are well correlated with correlation coefficients of 0.7 or higher for daytime data over both land and ocean. However, Fig. 9 also reveals significant biases between MOPITT retrievals and the trajectorymapped MOZAIC-IAGOS CO climatology (geometric) altitudes above the $700 \mathrm{hPa}$ pressure level. Although in Fig. 9 we have chosen to show biases for winter 2001-2012, the same analysis for other seasons yields similar results. 

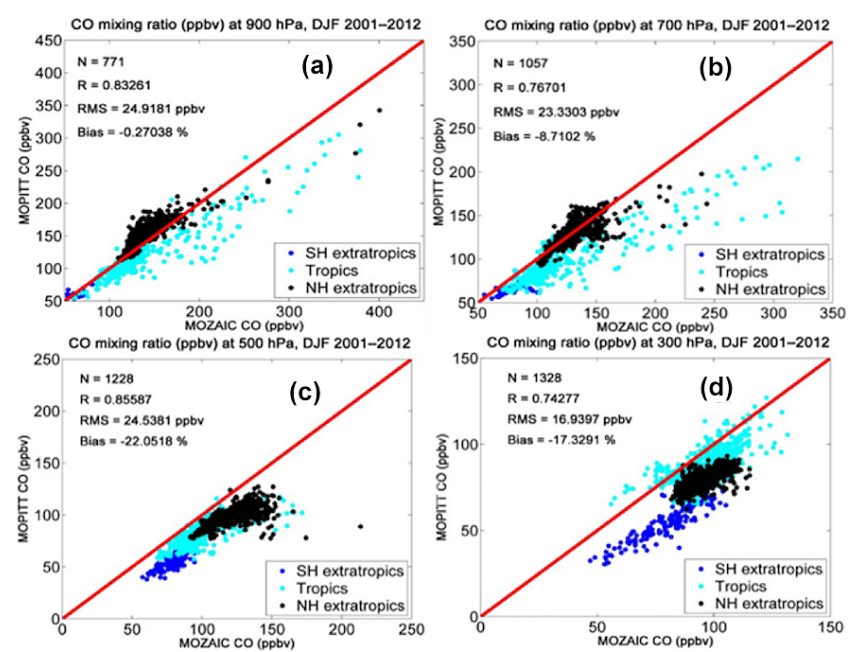

Figure 9. Comparison results for DJF (December, January, February) 2001-2012. MOPITT CO retrievals at 900, 700, 500, and $300 \mathrm{hPa}$ are plotted against trajectory-mapped MOZAIC-IAGOS CO climatology profiles that have been transformed using the MOPITT averaging kernels and a priori data. The red line is the $1: 1$ line, $N$ denotes the total number of data points, $R$ is the correlation coefficient, RMS is root mean square error in ppbv, and Bias is the relative bias between them in percent. In each panel, the different color dots group different latitude bands: $23.5-66.5^{\circ} \mathrm{S}$ ( $\mathrm{SH}$ extratropics), $23.5^{\circ} \mathrm{S}-23.5^{\circ} \mathrm{N}$ (tropics), and 23.5-66.5 $\mathrm{N}$ ( $\mathrm{NH}$ extratropics).

These large differences are surprising, since Deeter et al. (2014), who also use the MOPITT L3 V6 product and NOAA flask data (among other sources), report biases varying from $-5.2 \%$ at $400 \mathrm{hPa}$ to $8.9 \%$ at the surface. These results are not dissimilar to our comparison in Fig. 8 and would suggest a difference of about $5 \%$ between MOPITT and the trajectory-mapped climatology, with the climatology being higher primarily due to the airport effect. Although the validation data sets are not identical (owing primarily to incomplete global coverage of the MOZAIC-IAGOS product), the relative bias of $22 \%$ at $500 \mathrm{hPa}$ seems excessive. In order to eliminate the possibility that trajectory errors might be contributing to this bias, we have also compared MOZAICIAGOS in situ CO profiles against MOPITT retrievals. As an example in Fig. 10, we display the comparison between MOZAIC-IAGOS in situ CO profiles at Frankfurt (Germany) and MOPITT CO retrievals, which have been regridded to $5^{\circ}$ resolution, over Frankfurt from MOPITT overpasses. The MOZAIC-IAGOS in situ aircraft $\mathrm{CO}$ values have been transformed using the MOPITT averaging kernels and a priori data, for the period from December 2001 to December 2012. MOPITT and MOZAIC-IAGOS are again strongly correlated, and biases at 500 and $300 \mathrm{hPa}$ are large and in fact very similar in magnitude to those with respect to the trajectorymapped MOZAIC-IAGOS CO data set. This implies that the
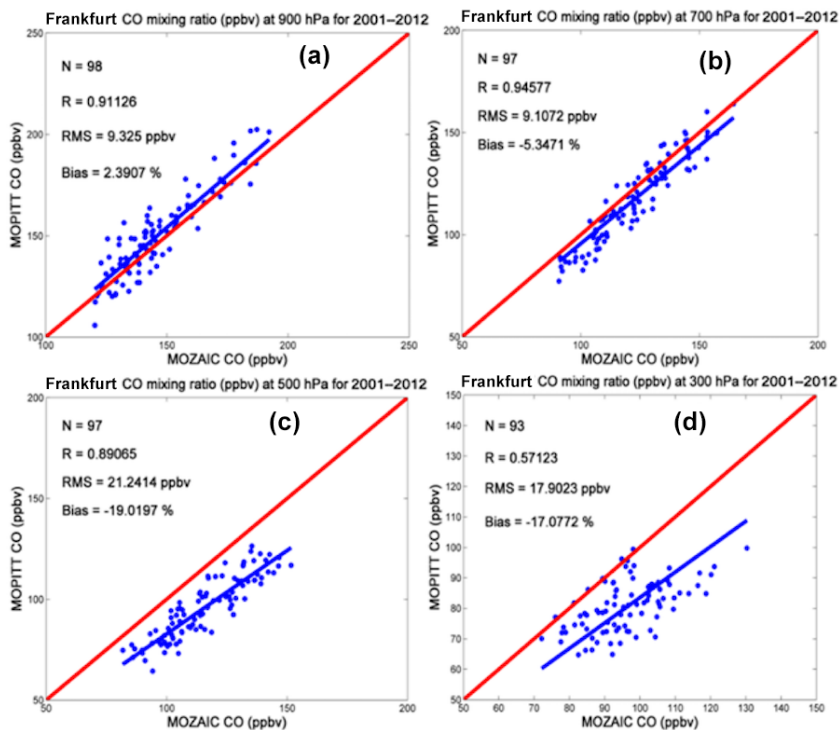

Figure 10. Same as Fig. 9 but MOPITT CO retrievals are plotted against MOZAIC-IAGOS CO in situ profiles that have been transformed using the MOPITT averaging kernels and a priori data. The in situ profiles are monthly means from 2001 to 2012 (Frankfurt, Germany). Outliers (CO mixing ratios more than 1.5 standard deviations from the mean at each pressure level) have been removed, which improves the correlation coefficient at $300 \mathrm{hPa}$ but makes no significant change in other derived parameters.

differences at 500 and $300 \mathrm{hPa}$ are not a result of the trajectory mapping.

A global comparison between the trajectory-mapped MOZAIC-IAGOS climatology and MOPITT at $600 \mathrm{hPa}$ is displayed in Fig. 11. As can be seen, both data sets capture major features of the $\mathrm{CO}$ distribution, particularly anthropogenically polluted (i.e., northeastern China) and biomass burning (i.e., West Africa, Central Africa, southern Africa, and Central America) regions. The CO-rich air in the lower troposphere over West Africa, where biomass burning fires are active, is convectively lifted to the upper troposphere where it disperses over the African tropics towards the east coast of South America (Edwards et al., 2003). Over southern Africa and Southeast Asia, where there are strong sources, and in general at $600 \mathrm{hPa}$, higher CO VMRs are found by the MOZAIC-IAGOS mapping than by MOPITT.

Figure S2 shows global maps of percentage differences between MOPITT and the transformed trajectory-mapped MOZAIC-IAGOS CO climatology at 800 and $600 \mathrm{hPa}$ pressure levels for DJF and SON 2001-2012. Differences are generally less than $\pm 20 \%$ at $800 \mathrm{hPa}$, with a negligible overall bias, but larger at $600 \mathrm{hPa}$, with MOPITT on average 10$20 \%$ lower. Generally, the comparisons of the $\mathrm{CO}$ profiles of the transformed trajectory-mapped MOZAIC-IAGOS and MOPITT for both grid cells as well as zonal mean for different latitude bands show a consistent, significant bias: MOPITT is lower from about 700 to $300 \mathrm{hPa}$ but shows a negli- 

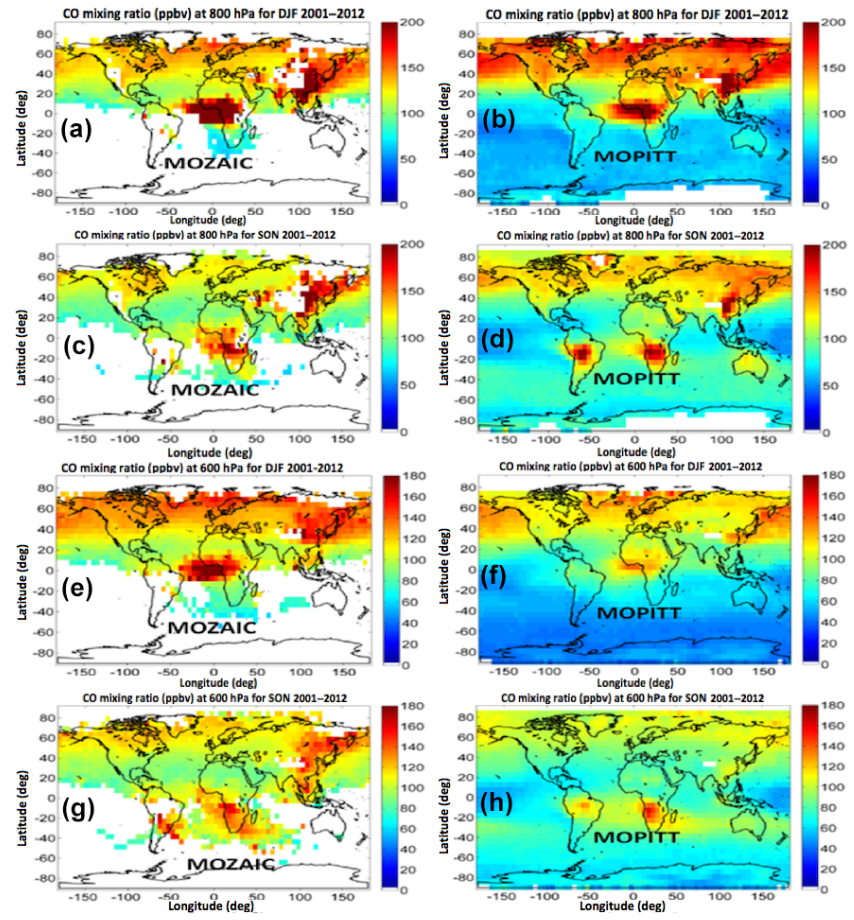

Figure 11. Global distribution of the seasonal mean trajectorymapped MOZAIC-IAGOS CO climatology (left panels), after transformation with the MOPITT a priori profiles and averaging kernels matrix, and MOPITT CO retrievals (right panels). CO mixing ratio (ppbv) as a function of latitude and longitude at 800 (a-d) and $600(\mathbf{e}-\mathbf{h}) \mathrm{hPa}$ pressure levels. Data are binned at $5^{\circ} \times 5^{\circ}$ in latitude and longitude for the period from 2001 to 2012.

gible bias in the lowermost troposphere. Above $300 \mathrm{hPa}$, they seem to agree better, although this may be partly due to the fact that the retrieved $\mathrm{CO}$ values in this region are highly influenced by the MOPITT a priori data for both cases.

\subsection{Comparison with MOPITT CO total column values}

In the same manner as we have done for the retrieved $\mathrm{CO}$ profiles, the retrievals of $\mathrm{CO}$ total column $c_{\text {ret }}$ may be compared against total column values derived from in situ profiles $\boldsymbol{x}$. Utilizing Eq. (2), the retrievals of the total CO column $c_{\text {ret }}$ found in Eq. (3) can be rewritten alternatively as

$c_{\text {ret }}=c_{\mathrm{a}}+\boldsymbol{a}\left(\boldsymbol{x}-\boldsymbol{x}_{\mathrm{a}}\right)$,

where $c_{\mathrm{a}}=\boldsymbol{t}^{T} \boldsymbol{x}_{\mathrm{a}}$ is the a priori total column value corresponding to the a priori profile $\boldsymbol{x}_{\mathrm{a}}, \boldsymbol{a}$ is the CO total column averaging kernel, and $\boldsymbol{x}$ is the in situ profile.

We have calculated the global total CO columns for both the MOZAIC-IAGOS CO climatology (using the MOPITT a priori and averaging kernels by applying Eq. 6) and for MOPITT CO retrievals and compared different regions of the globe and different time intervals from 2001 to 2012. For most regions the MOPITT CO total columns are 10-20\%
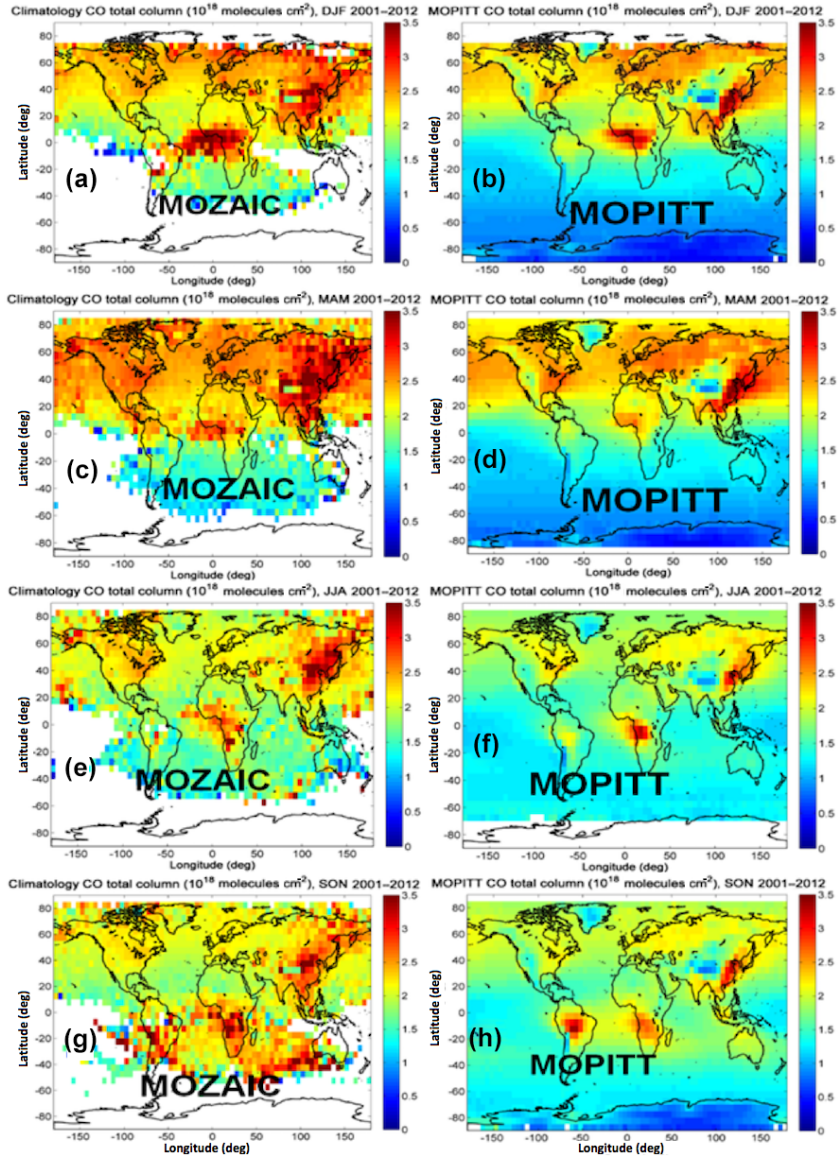

Figure 12. Global total column $\mathrm{CO}$ from the transformed trajectorymapped MOZAIC-IAGOS climatology and MOPITT data for December-February, March-May, June-August, and SeptemberNovember 2001-2012. Data are averaged in $5^{\circ} \times 5^{\circ}$ latitudelongitude bins.

lower than the trajectory-mapped MOZAIC-IAGOS CO climatology total columns, with larger differences in high $\mathrm{CO}$ source regions. The $\mathrm{SH}$ shows a distinct latitude gradient, which is not evident in the NH. This is likely related to the existence of major $\mathrm{CO}$ sources in the $\mathrm{NH}$ and the absence of large sources of emission in the SH. Figure 12 shows global total column $\mathrm{CO}$ for four seasons. It is clear that MOPITT and the climatology are similarly able to capture the $\mathrm{CO}$ spatial variability. In $\mathrm{NH}$ fall, elevated total column $\mathrm{CO}$ is seen over South America, Southeast Asia, and West Africa, which is due primarily to agricultural biomass burning in the regions. High total column $\mathrm{CO}$ is seen in all seasons over eastern China, which is one of the major emission regions in the world. NH total columns are much higher than those in the $\mathrm{SH}$, and $\mathrm{CO}$ is somewhat more abundant in the $\mathrm{NH}$ winter, which is expected due to the lower amounts of $\mathrm{OH}$ that are present in the troposphere in that season. Difference plots for the CO maps shown Fig. 12 are shown in Fig. S3. 

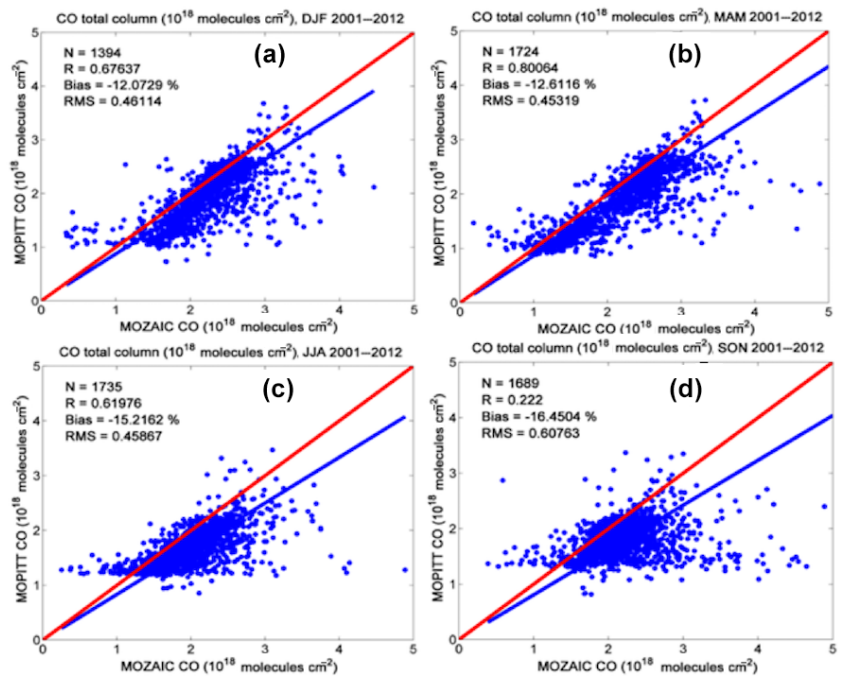

Figure 13. Global MOPITT CO column retrievals versus transformed trajectory-mapped MOZAIC-IAGOS CO climatology column for four seasons. The bias is calculated as the difference for each grid cell, [2(MOPITT-Clim)/(Clim+MOPITT)], averaged over all grid cells. The blue line is the line of best fit, the red line is the $1: 1$ line, and the correlation coefficient $(R)$, total number of data points $(N)$, and root mean square error (RMS) are indicated.

Figure 13 shows scatter plots of retrieved MOPITT CO total columns against the transformed trajectory-mapped MOZAIC-IAGOS climatology for the same periods shown in Fig. 12. Correlations are strong except in SON 20012012, and average biases are $12-16 \%$, with the trajectory MOZAIC-IAGOS higher. The high bias might be in part associated with the airport effect; however, the averaging kernels (Fig. 3) are not very sensitive to $\mathrm{CO}$ in the boundary layer.

\section{Results}

\subsection{Global distribution of MOZAIC-IAGOS CO climatology}

Figure 14 shows the monthly mean CO VMR between 4 and $8 \mathrm{~km}$ altitude above sea level for 2001-2012. The climatology is able to capture the $\mathrm{CO}$ spatial variability fairly well: the $\mathrm{NH}$ concentrations are much higher, and the biomass burning peaks are clearly visible for the $\mathrm{NH}$ winter and spring seasons. The climatology shows more abundant $\mathrm{CO}$ in the NH during these seasons. This is due primarily to lower $\mathrm{OH}$ levels during the cold season which permits a longer lifetime for $\mathrm{CO}$, although there also appears to be an additional source in eastern Asia. Enhanced CO concentration is observed in the tropical regions where wildfire burning is typical during January-April, like West Africa and a large part of Central Africa (Sauvage et al., 2005, 2007). At southern midlatitudes between South America, southern Africa, and
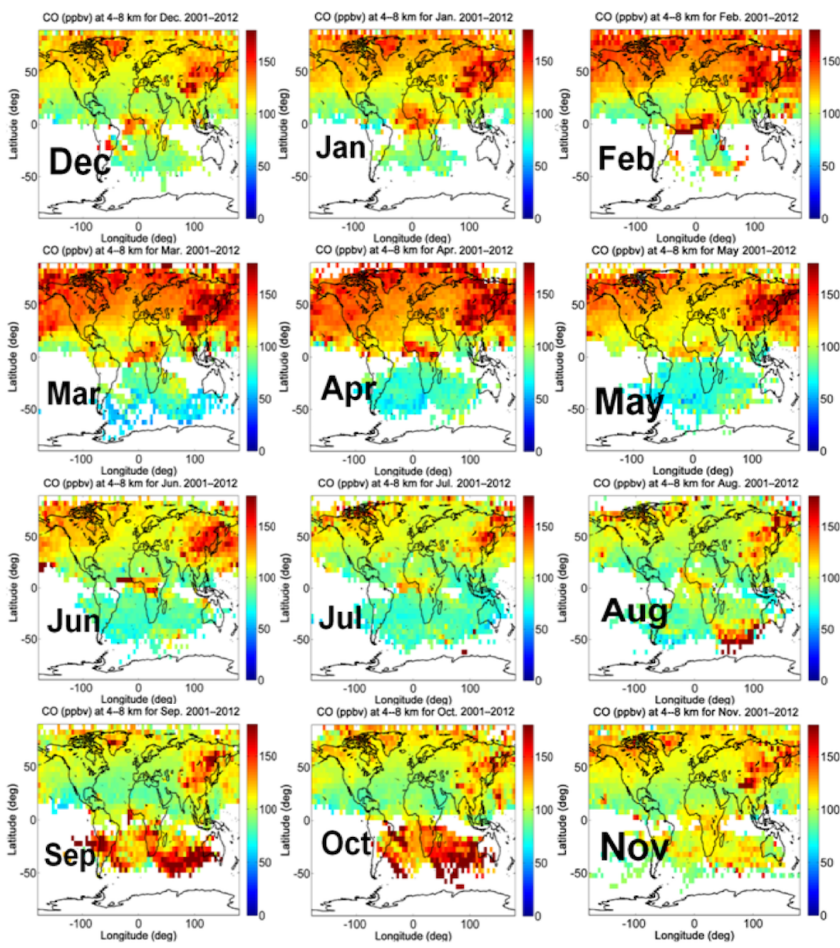

Figure 14. Global monthly mean $\mathrm{CO}$ distribution from the trajectory-mapped MOZAIC-IAGOS CO VMR as a function of latitude and longitude for January-December 2001-2012 and altitudes between 4 and $8 \mathrm{~km}$ a.s.l. The data are averaged with a bin size of $5^{\circ} \times 5^{\circ}$.

Australia, we observe high CO from September to November, during the agricultural burning season. Although Fig. 14 shows a 12-year global map, the strong enhanced CO over these regions (West Africa, South America, and Southeast Asia) is clearly observable as an annual feature with significant interannual variability.

\subsection{Zonal distribution of MOZAIC-IAGOS CO climatology}

\subsubsection{Seasonal variation}

As can be seen from Fig. 15, CO shows distinct seasonal cycles in both hemispheres. In the NH extratropics (Fig. 15c), maximum CO VMR is observed in February-April following a steady increase during fall and winter. This is followed by a rapid decrease to the lowest CO levels in JulySeptember. The decline in summer shows the typical seasonal pattern of $\mathrm{CO}$ in the $\mathrm{NH}$, driven by $\mathrm{OH}$ increase during this time (Yurganov et al., 2008; Novelli et al., 1998). In the SH extratropics (Fig. 15d), CO levels peak in SeptemberOctober. This is consistent with previous studies by Novelli et al. (1998). In the SH, the annual CO maximum is earlier at lower altitudes. Rinsland et al. (2002) suggested that this phenomenon is associated with the vertical and horizon- 

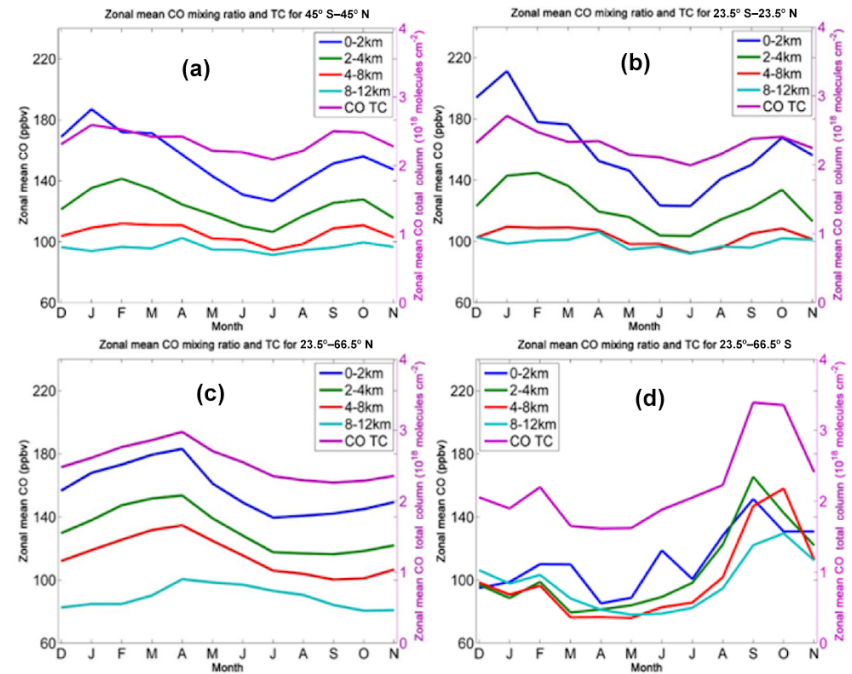

Figure 15. Zonally averaged monthly variation of $\mathrm{CO}$ for the latitude bands $45^{\circ} \mathrm{S}-45^{\circ} \mathrm{N}, 23.5^{\circ} \mathrm{S}-23.5^{\circ} \mathrm{N}, 23.5-66.5^{\circ} \mathrm{N}$, and $23.5-$ $66.5^{\circ} \mathrm{S}$, for the period 2001-2012. CO mixing ratios are shown for altitude ranges $0-2,2-4,4-8$, and $8-12 \mathrm{~km}$, as well as total column (TC).

tal $\mathrm{CO}$ dispersion away from the biomass burning region in the tropics. Moreover, $\mathrm{CO}$ shows greater seasonal variability, particularly at higher altitudes, in the SH than in the $\mathrm{NH}$. The seasonal $\mathrm{CO}$ cycle in the tropics (Fig. 15b) and for latitude band $45^{\circ} \mathrm{S}-45^{\circ} \mathrm{N}$ (Fig. 15a) both display a July minimum and a secondary maximum in October, while the primary maximum is in late $\mathrm{NH}$ winter/early spring. The $\mathrm{CO}$ cycle in both hemispheres is controlled by seasonal variations of OH (Logan et al., 1981; Bergamaschi et al., 2000; Novelli et al., 1998) and biomass burning in the tropics and, to a lesser degree, at boreal latitudes.

Figure 16 shows zonal mean latitude-time cross-section plots of CO VMR at $2.5,4.5,6.5,8.5,10.5$, and $12.5 \mathrm{~km}$ altitudes for the period 2001-2012. The latitude-time crosssection shows the seasonal cycle of zonal mean $\mathrm{CO}$ for different altitudes, as seen in the previous figures, and also the variation of the interhemispheric CO VMR gradient throughout the year. The strongest interhemispheric gradient occurs in March, at low altitude, and the smallest gradients are seen in northern summer. The gradient in NH spring reverses at higher altitudes and in $\mathrm{NH}$ fall, when it is especially strong, at higher altitudes. Plot $14 \mathrm{e}$ and $\mathrm{f}$ also clearly show the weak seasonal cycle in the $\mathrm{NH}$ upper troposphere compared to that in the $\mathrm{SH}$.

\subsubsection{Vertical distribution}

Figure 17 illustrates the variation of $\mathrm{CO}$ with altitude for the seasons in which we observe maximum CO levels in both the $\mathrm{SH}$ and NH (i.e., MAM and SON). The greatest CO VMRs are found at lower altitudes in both hemispheres, although
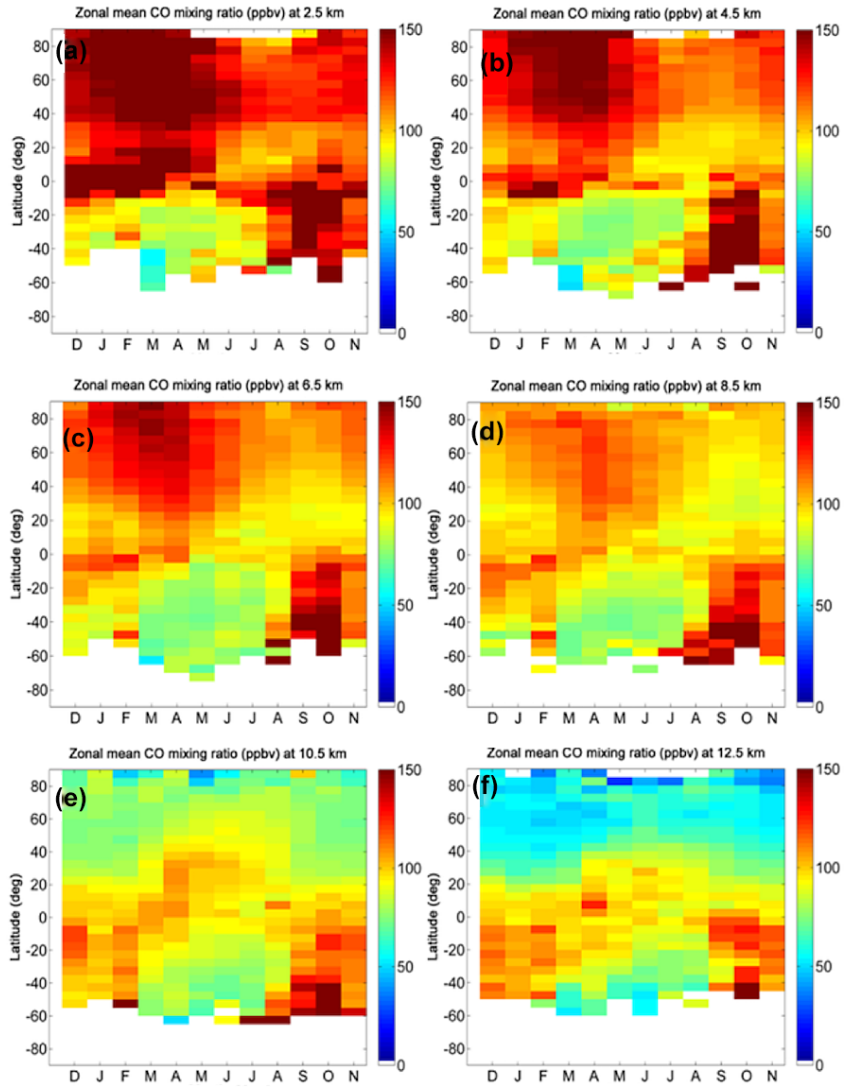

Figure 16. Seasonal variation of zonal monthly mean trajectorymapped MOZAIC-IAGOS CO climatology at 2.5, 4.5, 6.5, 8.5, 10.5 , and $12.5 \mathrm{~km}$ altitudes for the period 2001-2012. The zonal mean data are averaged in $5^{\circ}$ latitude intervals.

$\mathrm{CO}$ declines with altitude faster in the $\mathrm{NH}$ than the SH. This results in a decrease in the strength of the interhemispheric gradient ( $\mathrm{SH}$ to $\mathrm{NH}$ ) with altitude. This result is consistent with Edwards et al. (2006), who suggested that in the absence of continued $\mathrm{CO}$ input from the source regions (i.e., biomass burning in southern Africa and South America), the aged CO is gradually distributed vertically throughout the troposphere in the SH. In fact, in regions where there is deep convection this leads to an enhanced $\mathrm{CO}$ concentration in the upper troposphere, as can be seen on the right-hand side of Fig. 17 and in Fig. 18. Moreover, Liu et al. (2006) showed large horizontal CO gradients in association with vertical and horizontal transport of air with different chemical signatures of origin.

Zonal CO mean vertical profiles for February, April, July, and September, averaged for 2001-2012 over the latitude bands $23.5-66.5^{\circ} \mathrm{N}$ ( $\mathrm{NH}$ extratropics), 23.5-66.5 ${ }^{\circ} \mathrm{S}$ ( $\mathrm{SH}$ extratropics), and $23.5^{\circ} \mathrm{S}-23.5^{\circ} \mathrm{N}$ (tropics), are shown in Fig. 18. The $\mathrm{CO}$ profiles show seasonal and latitudinal variability primarily in the NH extratropics. The largest VMRs of $\mathrm{CO}$ occur at lower altitudes in the NH extratropics in February and April but the strong decline with altitude causes $\mathrm{CO}$ VMRs to be higher in the $\mathrm{SH}$ at high altitudes than in the 

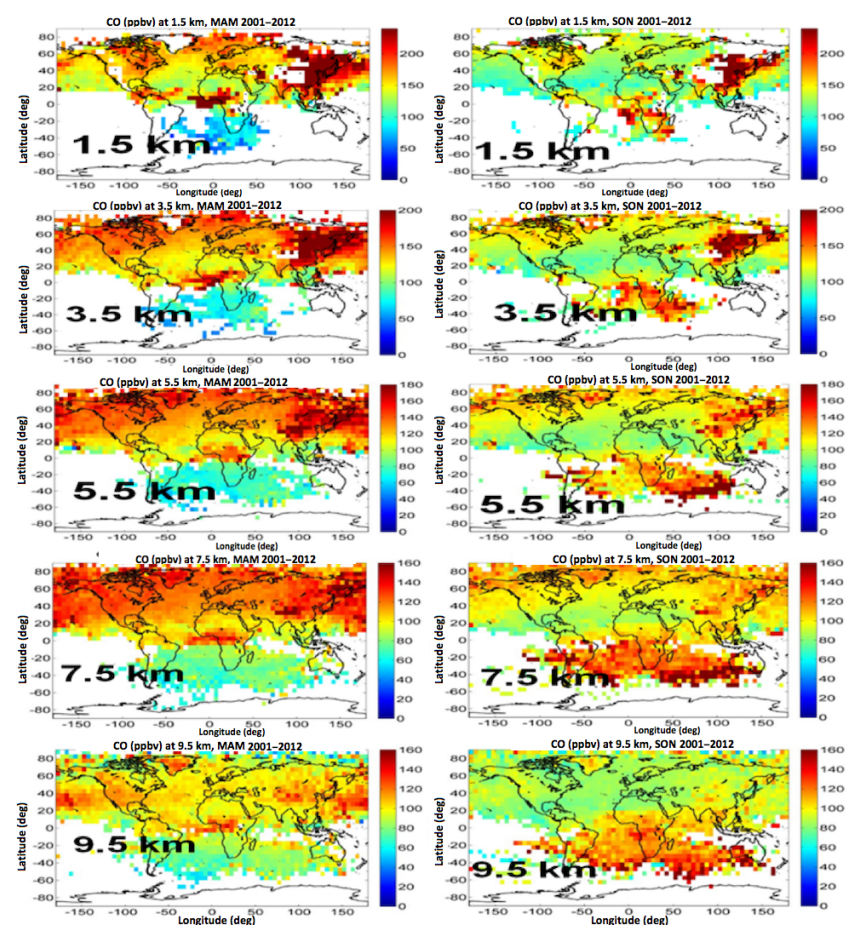

Figure 17. Global distribution of seasonal (the NH spring and fall) mean trajectory-mapped MOZAIC-IAGOS CO climatology as a function of latitude and longitude for altitudes 1.5, 3.5, 5.5, 7.5, and $9.5 \mathrm{~km}$ a.s.l. The left and right columns show average CO VMRs for March-April-May and September-October-November, 20012012. The data are averaged with a bin size of $5^{\circ} \times 5^{\circ}$ latitude and longitude.

$\mathrm{NH}$. The trajectory-mapped $\mathrm{CO}$ in the $\mathrm{SH}$ extratropics is mainly representative of the tropics, while in the $\mathrm{NH}$ extratropics there are many $\mathrm{CO}$ measurements poleward of $40^{\circ}$. This implies that sampling of the lowermost stratosphere will be more frequent in the $\mathrm{NH}$ than in the $\mathrm{SH}$. In the tropics, CO VMRs show a rapid decrease with altitude in the lower troposphere but above approximately $4-5 \mathrm{~km}$ changes with altitude are minor.

\section{Applications}

\subsection{Global variation and trends of $\mathrm{CO}$}

The smoothed time series of the NH extratropical zonal mean CO VMR at 900, 700, 500, and $300 \mathrm{hPa}$ for the trajectorymapped MOZAIC-IAGOS data set 2001-2012 is shown in Fig. 19. For purposes of comparison we also show data from MOPITT and from the mapped MOZAIC-IAGOS data set transformed with the MOPITT averaging kernels. Gaps in the figure occur whenever one data source is missing. The gaps in June-July 2001 and August-September 2009 were due to a cooler failure of the MOPITT instrument. MOZAICIAGOS began CO measurement in December 2001 and
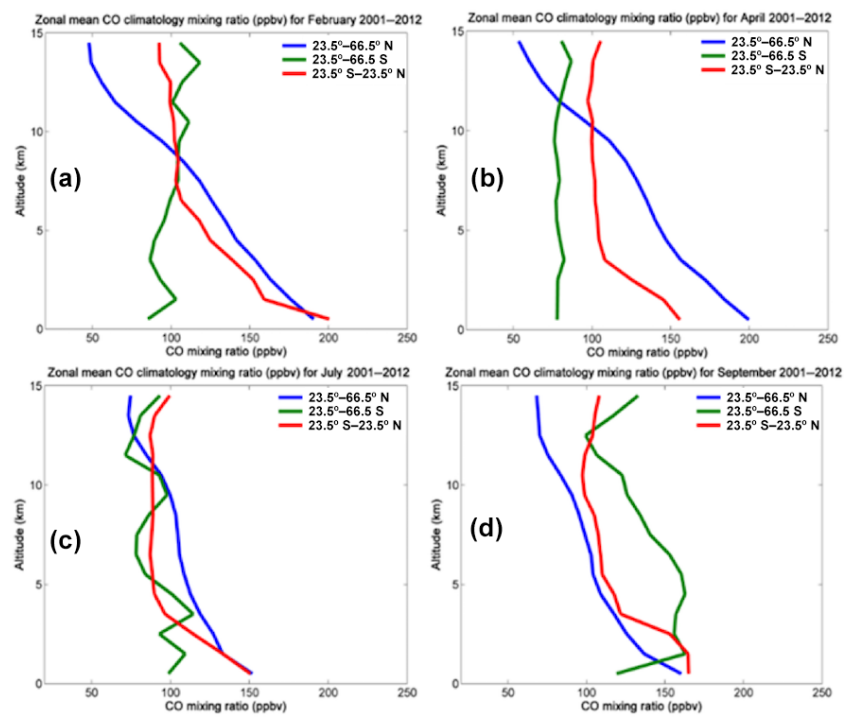

Figure 18. Monthly mean profiles of $\mathrm{CO}$ from the trajectorymapped MOZAIC-IAGOS CO climatology for February, April, July, and September, averaged for 2001-2012. The different colors represent $\mathrm{CO}$ mean VMR for the latitude bands $23.5-66.5^{\circ} \mathrm{N}$, $23.5-66.5^{\circ} \mathrm{S}$, and $23.5^{\circ} \mathrm{S}-23.5^{\circ} \mathrm{N}$.

there were only partial data available in 2010 and 2011 . The observations show an annual late winter or springtime peak in the $\mathrm{NH}$ extratropical zonal $\mathrm{CO}$ loading each year, in conjunction with low wintertime $\mathrm{OH}$ levels. The same interannual cycle of $\mathrm{CO}$ is captured by both trajectorymapped MOZAIC-IAGOS (transformed and untransformed) and MOPITT. They appear to track short-term changes equally well. However, while all show a modest decline in the lower troposphere until about 2008-2009 (after which CO VMR seems to level off), in accordance with the trends found by Worden et al. (2013), in the upper troposphere MOPITT shows a modest increase. It also shows a significant bias with respect to the trajectory-mapped MOZAIC-IAGOS data that decreases with time. Although the untransformed trajectory-mapped MOZAIC-IAGOS CO values show a significant difference against the transformed data in the lower troposphere, they seem to agree well at higher levels. The untransformed trajectory-mapped MOZAIC-IAGOS data show higher CO levels than MOPITT CO retrievals at all levels.

Laken and Shahbaz (2014) found increasing CO trends over widespread regions of South America, Mexico, Central Africa, Greenland, the eastern Antarctic, and the entire region of India and China from MOPITT data. The SH extratropics also show time series similar to those in Fig. 19, but the negative trend is not as clear as that in the $\mathrm{NH}$ due to limited data. The annual springtime peak in the $\mathrm{SH}$ zonal $\mathrm{CO}$ loading is visible in all of the time series. This is predominantly associated with dry season biomass burning emissions in South America, southern Africa, Southeast Asia, and northwestern Australia. In later months, the CO result- 


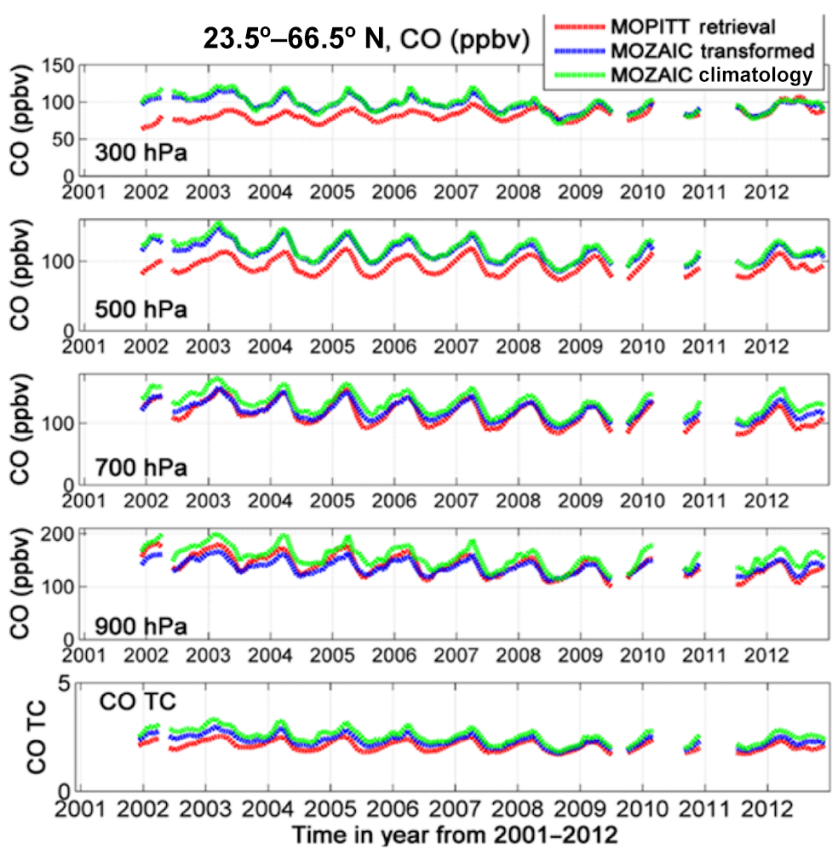

Figure 19. Zonally averaged time series of monthly mean $\mathrm{CO}$ VMR, at individual levels and total column, as retrieved by MOPITT and from the trajectory-mapped MOZAIC-IAGOS CO climatology (untransformed, and transformed using MOPITT's averaging kernels) for the latitude band $23.5-66.5^{\circ} \mathrm{N}$.

ing from these emissions is generally destroyed by more active photochemistry during the SH summer. At these times, the retrieved zonal $\mathrm{CO}$ falls to background levels (around $40-50 \mathrm{ppbv}$ ), which are representative of the remote ocean regions where $\mathrm{CO}$ production by methane oxidation is the dominant source (Edwards et al., 2006). We looked at the time series of the zonal monthly mean of CO VMR for the tropics. The biases between the MOPITT retrievals and the trajectory-mapped MOZAIC-IAGOS in general show the same features as for the extratropics, while the seasonal patterns combine those of the NH and SH seen in Fig. 19.

In Fig. S4, we display the monthly mean time series for Frankfurt from December 2001 to December 2012. These also show significant biases, declining with time, between MOPITT and the transformed MOZAIC-IAGOS in situ above $700 \mathrm{hPa}$, in good agreement with the result shown in Fig. 19. Furthermore, MOPITT shows a modest increase in CO levels in the upper troposphere while MOZAIC-IAGOS in situ (transformed and untransformed) shows a modest decline, consistent with Petetin et al. (2015), who report a similar decrease over Frankfurt. The MOPITT and MOZAICIAGOS (transformed and untransformed) $\mathrm{CO}$ values for Frankfurt show the same seasonal patterns as the NH extratropics (Fig. 19). This comparison suggests that a prominent bias, declining with time, exists between MOZAIC-IAGOS and MOPITT L3 V6 TIR/NIR products.

\section{Conclusions}

We have presented a three-dimensional (i.e., latitude, longitude, altitude) gridded climatology of $\mathrm{CO}$ developed by trajectory mapping of global MOZAIC-IAGOS data. This quasi-global climatology data set offers a complement to global satellite measurements, at significantly higher vertical resolution, that facilitates visualization and comparison of different years and seasons and offers insight into the global variation and trends of $\mathrm{CO}$. Even though the MOZAICIAGOS aircraft data are unevenly distributed both in time and space across the globe, the trajectory-mapped data set is uniformly distributed on a $5^{\circ} \times 5^{\circ} \times 1 \mathrm{~km}$ grid. Major regional features of the global $\mathrm{CO}$ distribution are clearly evident in the $\mathrm{CO}$ maps for different seasons and altitudes. The trajectory-mapped $\mathrm{CO}$ shows distinct seasonal cycles with the $\mathrm{CO}$ annual maximum occurring in September-October in the $\mathrm{SH}$, coincident with the tropical biomass burning season (Rinsland et al., 2002), and in April in the NH, while the tropics show distinct maxima in January-February and in October. We caution that the observed result in the $\mathrm{SH}$ is obtained from the limited data we have from the region. The interhemispheric $\mathrm{CO}$ gradient is strongest in late winter/early spring and smallest in northern summer. Time series analysis of the climatology shows that in the $\mathrm{NH}$ and the tropics $\mathrm{CO}$ is declining with time. This is consistent with previous studies using ground-based, aircraft, and satellite data, such as Petetin et al. (2015), Worden et al. (2013), Laken and Shahbaz (2014), and Novelli et al. (1998). The consistency of our findings with those from other global data sets lends increased confidence that the $\mathrm{CO}$ data set derived from trajectory mapping of global MOZAIC-IAGOS data can be used for $\mathrm{CO}$ trend studies at regional and global scales.

The trajectory-mapped $\mathrm{CO}$ data set has been validated by comparing maps constructed using only forward trajectories and using only backward trajectories. The two methods show similar global CO distribution patterns. Differences are most commonly $10 \%$ or less and found to be less than $30 \%$ for almost all cases. They are typically less than $10 \%$ at northern midlatitudes and less than $20 \%$ in the tropics between $\pm 30^{\circ}$ latitude, except in the Pacific and Atlantic oceans where they can reach as large as $30 \%$. The data set has also been validated by comparison against in situ MOZAIC-IAGOS aircraft measurements, where the data from the validation site are excluded from the trajectory-mapped data. Although the comparison shows larger differences below $2 \mathrm{~km}$, the profiles from the two methods agree very well between 2 and $10 \mathrm{~km}$ with the magnitude of differences within $20 \%$. A further comparison between the trajectory-mapped result and MOZAIC-IAGOS in situ CO cruise data, which were not included in the trajectory-mapping, shows that major regional features of the global $\mathrm{CO}$ distribution for different seasons are clearly evident in both maps and they agree well in regions of overlap. This suggests that the trajectory-mapped $\mathrm{CO}$ data perform well not only near airports but also in 
remote areas. Validation was also performed against independent data from the NOAA aircraft flask sampling program. The results suggest small or insignificant biases in the upper troposphere but positive biases as large as $12 \%$ for MOZAIC-IAGOS in the lower troposphere. This is probably due to the "airport effect", a sampling bias that occurs because commercial aircraft operate from large airports near large cities, with typically elevated $\mathrm{CO}$ levels in the boundary layer.

The trajectory-mapped $\mathrm{CO}$ data set has also been extensively compared with MOPITT retrievals. Between 700 and $300 \mathrm{hPa}$, a prominent bias, declining with time, exists between MOZAIC-IAGOS and MOPITT L3 V6 TIR/NIR products.

This study demonstrates one aspect of the value of the MOZAIC-IAGOS continuous, long-term, global, vertically resolved in situ measurements. Such routine commercial aircraft observations provide valuable information on atmospheric composition that can improve our understanding of global and regional air quality and the potential impact of greenhouse gases on climate change. The unique 3-D CO climatology data set presented here has the potential to be used for time series and trend analysis and provides a quasiglobal view of $\mathrm{CO}$ changes and transport as well as interannual variability. It will also be useful as model initial fields and background and boundary fields. It will be especially useful as an improved a priori climatology for satellite data retrieval. The global picture it presents is also expected to be valuable for comparison and validation of model results. The data are publicly available at ftp://es-ee.tor.ec.gc.ca/pub/ ftpdt/MOZAIC_output_CO/.

\section{Data availability}

The trajectory-mapped MOZAIC-IAGOS CO climatology data set is publicly available at ftp://es-ee.tor.ec.gc.ca/pub/ ftpdt/MOZAIC_output_CO/.

\section{The Supplement related to this article is available online at doi:10.5194/acp-16-10263-2016-supplement.}

Acknowledgements. The authors acknowledge the strong support of the European Commission, Airbus, and the airlines (Lufthansa, Air France, Austrian, Air Namibia, Cathay Pacific, Iberia, and China Airlines so far) that carry the MOZAIC or IAGOS equipment and perform the maintenance since 1994. MOZAIC is presently funded by INSU-CNRS (France), Météo-France, Université Paul Sabatier (Toulouse, France), and Research Center Jülich (FZJ, Jülich, Germany). IAGOS has been additionally funded by the EU projects IAGOS-DS and IAGOS-ERI. The MOZAIC-IAGOS database is supported by ETHER (CNES and INSU-CNRS). Data are also available via the Ether web site http://www.pole-ether.fr.
We thank the many whose dedication makes such a data set possible. The MOPITT data were obtained from the NASA Langley Research Center Atmospheric Science Data Center. We thank R. Draxler and the NOAA Air Resources Laboratory for the trajectory model HYSPLIT and NCEP/NCAR for the global meteorological reanalysis data. The first author is grateful to the Natural Sciences and Engineering Research Council of Canada (NSERC) and Environment Canada for a research fellowship. Important discussions with Merritt Deeter regarding MOPITT averaging kernels are much appreciated. We thank Paul Novelli and Colm Sweeney of NOAA/Earth System Research Laboratory and Steven Wofsy of Harvard University/School of Engineering and Applied Sciences for providing the in situ CO profiles.

Edited by: R. Müller

Reviewed by: three anonymous referees

\section{References}

Bergamaschi, P., Hein, R., Heimann, M., and Crutzen, P. J.: Inverse modeling of the global CO cycle: 1 . Inversion of CO mixing ratios, J. Geophys. Res., 105, 1909, doi:10.1029/1999JD900818, 2000.

Boden, T. A., Marland, G., and Andres, R. J.: Global, Regional, and National Fossil-Fuel $\mathrm{CO}_{2}$ Emissions. Carbon Dioxide Information Analysis Center, Oak Ridge Natl. Lab., U.S. Dep. of Energy, Oak Ridge, Tenn., doi:10.3334/CDIAC/00001, available at: http://cdiac.ornl.gov/trends/emis/cpa.html) (last access: 8 September 2015), 2009.

Brook, J. R., Dann, T. F., Galarneau, E., Herod, D., and Charland, J.-P.: The State of Air Quality in Canada: National Patterns, in: Air Quality Management, Canadian Perspectives on a Global Issue, Springer, Dordrecht, ISBN 978-94-007-7557-2, 43-67, doi:10.1007/978-94-007-7557-2, 2014.

Cai, H. and Xie, S.: Estimation of vehicular emission inventories in China from 1980 to 2005, Atmos. Environ., 44, 8963-8979, 2007.

Carmichael, G. R., Tang, Y., Kurata, G., Uno, I., Streets, D. G., Woo, J.-H., Huang, H., Yienger, J., Lefer, B., Shetter, R. E., Blake, D. R., Atlas, E., Fried, A., Apel, E., Eisele, F., Cantrell, C., Avery, M. A., Barrick, J. D., Sachse, G. W., Brune, W. L., Sandholm, S. T., Kondo, Y., Singh, H. B., Talbot, R. W., Bandy, A., Thorton, D., Clarke, A. D., and Heikes, B. G.: Regional-scale chemical transport modeling in support of intensive field experiments: Overview and analysis of the TRACE-P observations, J. Geophys. Res., 108, 8823, doi:10.1029/2002JD003117, 2003.

Chameides, W. L., Kasibhatla, P. S., Yienger, J. J., Levy II, H., and Moxim, W. J.: The growth of continental-scale metro-agroplexes, regional ozone pollution, and world food production, Science, 264, 74-77, 1994.

Clark, H., Sauvage, B., Thouret, V., Nédélec, P., Blot, R., Wang, K. Y., Smit, H., Neis, P., Petzold, A., Athier, G., Boulanger, D., Cousin, J.-M., Beswick, K., Gallagher, M., Baumgardner, D., Kaiser, J., Flaud, J.-M., Wahner, A., Volz-Thomas, A., and Cammas, J.-P.: The first regular measurements of ozone, carbon monoxide and water vapour in the Pacific UTLS by IAGOS, Tellus B, 67, 28385, doi:10.3402/tellusb.v67.28385, 2015. 
Conway, T. J., Tans, P. P., Waterman, L. S., Thoning, K. W., Kitzis, D. R., Masarie, K. A., and Zhang, N.: Evidence for interannual variability of the carbon cycle from the NOAA/CMDL global air sampling network, J. Geophys. Res., 99, 22831-22855, 1994.

Crutzen, P.: A discussion of the chemistry of some minor constituents in the stratosphere and troposphere, Pure Appl. Geophys., 106, 1385-1399, doi:10.1007/BF00881092, 1973.

Deeter, M. N.: Calculation and Application of MOPITT (Measurements of Pollution in the Troposphere) Averaging Kernels, available at: http://www.acom.ucar.edu/mopitt/data/avgkrnls_app.pdf (last access: 20 April 2016), 2002.

Deeter, M. N.: MOPITT (Measurements of Pollution in the Troposphere) Validated Version 5 Product User's Guide, National Center for Atmospheric Research, available at: http://www.acom. ucar.edu/mopitt/v5_users_guide_beta.pdf, 2011.

Deeter, M. N., Emmons, L. K., Edwards, D. P., Gille, J. C., and Drummond, J. R.: Vertical resolution and information content of CO profiles retrieved by MOPITT, Geophys. Res. Lett., 31, L15112, doi:10.1029/2004GL020235, 2004.

Deeter, M. N., Edwards, D. P., Gille, J. C., Emmons, L. K., Francis, G., Ho, S.-P., Mao, D., Masters, D., Worden, H., Drummond, J. R., and Novelli, P.: The MOPITT Version 4 CO Product: Algorithm Enhancements, Validation, and Long-Term Stability, J. Geophys. Res., 115, D07306, doi:10.1029/2009JD013005, 2010.

Deeter, M. N., Worden, H. M., Edwards, D. P., Gille, J. C., and Andrews, A. E.: Evaluation of MOPITT retrievals of lowertropospheric carbon monoxide over the United States, J. Geophys. Res., 117, D13306, doi:10.1029/2012JD017553, 2012.

Deeter, M. N., Martínez-Alonso, S., Edwards, D. P., Emmons, L. K., Gille, J. C., Worden, H. M., Pittman, J. V., Daube, B. C., and Wofsy, S. C.: Validation of MOPITT Version 5 thermalinfrared, near-infrared, and multispectral carbon monoxide profile retrievals for 2000-2011, J. Geophys. Res., 118, 6710-6725, doi:10.1002/jgrd.50272, 2013.

Deeter, M. N., Martínez-Alonso, S., Edwards, D. P., Emmons, L. K., Gille, J. C., Worden, H. M., Sweeney, C., Pittman, J. V., Daube, B. C., and Wofsy, S. C.: The MOPITT Version 6 product: algorithm enhancements and validation, Atmos. Meas. Tech., 7, 3623-3632, doi:10.5194/amt-7-3623-2014, 2014.

Ding, K., Liu, J., Ding, A., Liu, Q., Zhao, T. L., Shi, J., Han, Y., Wang, H., and Jiang, F.: Uplifting of carbon monoxide from biomass burning and anthropogenic sources to the free troposphere in East Asia, Atmos. Chem. Phys., 15, 2843-2866, doi:10.5194/acp-15-2843-2015, 2015.

Draxler, R. R.: HYSPLIT4 user's guide, NOAA Tech. Memo, ERL ARL-230, NOAA Air Resourcesn Laboratory, Silver Spring, MD, 1999.

Draxler, R. R. and Hess, G. D.: An overview of the Hysplit_4 modeling system for trajectories, dispersion, and deposition, Austr. Meteorol. Mag., 47, 295-308, 1998.

Drummond, J. R. and Mand, G. S.: The Measurements of Pollution in the Troposphere (MOPITT) instrument: Overall performance and calibration requirements, J. Atmos. Ocean. Tech., 13, 314320, 1996.

Edwards, D. P., Halvorson, C., and Gille, J. C.: Radiative transfer modeling of the EOS Terra Satellite Measurements of Pollution in the Troposphere (MOPITT) instrument, J. Geophys. Res., 104, 16755-16775, 1999.
Edwards, D. P., Lamarque, J.-F., Attié, J.-L., Emmons, L. K., Richter, A., Cammas, J.-P., Gille, J. C., Francis, G. L., Deeter, M. N., Warner, J., Ziskin, D. C., Lyjak, L. V., Drummond, J. R., and Burrows, J. P.: Tropospheric ozone over the tropical Atlantic: A satellite perspective, J. Geophys. Res., 108, 4237, doi:10.1029/2002JD002927, 2003.

Edwards, D. P., Petron, G., Novelli, P. C., Emmons, L. K., Gille, J. C., and Drummond, J. R.: Southern Hemisphere carbon monoxide interannual variability observed by Terra/Measurement of Pollution in the Troposphere (MOPITT), J. Geophys. Res., 111, D16303, doi:10.1029/2006JD007079, 2006.

Emmons, L. K., Gille, J. C., Edwards, D. P., Attieé, J.-L, Warner, J., Ziskin, D., Francis, G., Khattatov, B., Yudin, V., Lamarque, J.-F., Ho, S.-P., Mao, D., Chen, J. S., Drummond, J., Novelli, P., Sachse, G., Coffey, M. T., Hannigan, J. W., Gerbig, C., Kawakami, S., Kondo, Y., Takegawa, N., Schlager, H., Baehr, J., and Ziereis, H.: Validation of Measurements of Pollution in the Troposphere (MOPITT) CO retrievals with aircraft in situ profiles, J. Geophys. Res., 109, D03309, doi:10.1029/2003JD004101, 2004.

Emmons, L. K., Pfister, G. G., Edwards, D. P., Gille, J. C., Sachse, G., Blake, D., Wofsy, S., Gerbig, C., Matross, D., and Nédélec, P.: Measurements of Pollution in the Troposphere (MOPITT) validation exercises during summer 2004 field campaigns over North America, J. Geophys. Res., 112, D12S02, doi:10.1029/2006JD007833, 2007.

Emmons, L. K., Edwards, D. P., Deeter, M. N., Gille, J. C., Campos, T., Nédélec, P., Novelli, P., and Sachse, G.: Measurements of Pollution In The Troposphere (MOPITT) validation through 2006, Atmos. Chem. Phys., 9, 1795-1803, doi:10.5194/acp-91795-2009, 2009.

Fishman, J. and Seiler, W.: Correlative Nature of Ozone and Carbon Monoxide in the Troposphere: Implications for the Tropospheric Ozone Budget, J. Geophys. Res., 88, 3662-3670, 1983.

Galanter, M., Levy II, H., and Carmichael, G. R.: Impacts of biomass burning on tropospheric CO, NOx, and Os, J. Geophys. Res., 105, 6633-6653, 2000.

Granier, C., Bessagnet, B., Bond, T., D’Angiola, A., v. d. Gon, H. D., Frost, G. J., Heil, A., Kaiser, J. W., Kinne, S., Klimont, Z., Kloster, S., Lamarque, J.-F., Liousse, C., Masui, T., Meleux, F., Mieville, A., Ohara, T., Raut, J.-C., Riahi, K., Schultz, M. G., Smith, S. J., Thomson, A., v. Aardenne, J., v. d. Werf, G. R., and v. Vuuren, D. P.: Evolution of anthropogenic and biomass burning emissions of air pollutants at global and regional scales during the 1980-2010 period, Climatic Change, 109, 163-190, doi:10.1007/s10584-011-0154-1, 2011.

Gregg, J. S., Andres, R. J., and Marland, G.: China: Emissions pattern of the world leader in $\mathrm{CO}_{2}$ emissions from fossil fuel consumption and cement production, Geophys. Res. Lett., 35, L08806, doi:10.1029/2007GL032887, 2008.

Heald, C. L., Jacob, D. J., Jones, D. B. A., Palmer, P. I., Logan, J. A., Streets, D. G., Sachse, G. W., Gille, J. C., Hoffman, R. N., and Nehrkorn, T.: Comparative inverse analysis of satellite (MOPITT) and aircraft (TRACE-P) observations to estimate Asian sources of carbon monoxide, J. Geophys. Res., 109, D15S04, doi:10.1029/2004JD005185, 2004.

Holloway, T., Levy II, H., and Kasibhatla, P.: Global distribution of carbon monoxide, J. Geophys. Res., 105, 12123-12147, 2000. 
Hubler, G., Montzka, D. D., Norton, R. B., Murphy, P. C., Fehsenfeld, F. C., Liu, S. C., Ridley, B. A., Walega, J. G., Atlas, E., Grahek, F. E., Heidt, L. E., Merrill, J., Huebert, B. J., and Bodhaine, B. A.: Total reactive oxidized nitrogen (NOy) in the remote pacific troposphere and its correlation with $\mathrm{O}_{3}$ and $\mathrm{CO}$ : Mauna Loa Observatory Photochemistry Experiment 1988, 25, J. Geophys. Res., 97, 10427-10447, 1992.

IPCC (IPCC AR5): Climate Change 2013: The Physical Science Basis. Contribution of Working Group I to the Fifth Assessment Report of the Intergovernmental Panel on Climate Change, edited by: Stocker, T. F., Qin, D., Plattner, G.-K., Tignor, M., Allen, S. K., Boschung, J., Nauels, A., Xia, Y., Bex, V., and Midgley, P. M., Cambridge University Press, Cambridge, United Kingdom and New York, NY, USA, 1535 pp., 2013.

Jacob, D. J., Crawford, J. H., Kleb, M. M., Connors, V. S., Bendura, R. J., Raper, J. L., Sachse, G. W., Gille, J. C., Emmons, L., and Heald, C. L.: Transport and Chemical Evolution over the Pacific (TRACE-P) aircraft mission: Design, execution, and first results, J. Geophys. Res., 108, 9000, doi:10.1029/2002JD003276, 2003.

Jaffe, D. A., Honrath, R. E., Zhang, L., Akimoto, H., Shimizu, A., Mukai, H., Murano, K., Hatakeyama, S., and Merrill, J.: Measurements of $\mathrm{NO}, \mathrm{NOy}, \mathrm{CO}$, and $\mathrm{O}_{3}$ and estimation of the ozone production rate at Oki Island, Japan during PEM-West, J. Geophys. Res., 101, 2037-2048, 1996.

Kalnay, E., Kanamitsu, M., Kistler, R., Collins, W., Deaven, D., Gandin, L., Iredell, M., Saha, S., White, G., Woollen, J., Zhu, Y., Leetmaa, A., Reynolds, R., Chelliah, M., Ebisuzaki, W., Higgins, W., Janowiak, J., Mo, K. C., Ropelewski, C., Wang, J., Jenne, R., and Joseph, D.: The NCEP/NCAR 40-year reanalysis project, B. Am. Meteorol. Soc., 77, 437-471, 1996.

Khalil, M. A. K. and Rasmussen, R. A.: Carbon monoxide in the Earth's atmosphere: Indications of a global increase, Nature, 332, 242-245, 1988.

Khalil, M. A. K. and Rasmussen, R. A.: Global decrease in atmospheric carbon monoxide concentration, Nature, 370, 639-641, 1994.

Laken, B. and Shahbaz, T.: Satellite-Detected Carbon Monoxide Pollution during 2000-2012: Examining Global Trends and also Regional Anthropogenic Periods over China, the EU and the USA, Climate, 2, 1-16, doi:10.3390/cli2010001, 2014.

Lang, P. M., Steele, L. P., Waterman, L. S., Martin, R. C., Masarie, K. A., and Dlugokencky, E. J.: NO AA/CMDL atmospheric methane data for the period 1983-1990 from shipboard flask sampling NOAA Tech. Memo., ERL CMDL-4, 88 pp., 1992.

Law, K. S. and Pyle, J. A.: Modeling trace gas budgets in the troposphere 2. $\mathrm{CH}_{4}$ and CO, J. Geophys. Res., 98, 18401-18412, doi:10.1029/93JD01480, 1993.

Lelieveld, J., Crutzen, P. J., Ramanathan, V., Andreae, M. O., Brenninkmeijer, C. A. M., Campos, T., Cass, G. R., Dickerson, R. R., Fischer, H., de Gouw, J. A., Hansel, A. Jefferson, A., Kley, D., de Laat, A. T. J., Lal, S., Lawrence, M. G., Lobert, J. M., MayolBracero, O. L., Mitra, A. P., Novakov, T., Oltmans, S. J., Prather, K. A., Reiner, T., Rodhe, H., Scheeren, H. A., Sikka, D., and Williams, J.: The Indian Ocean Experiment: Widespread air pollution from south and Southeast Asia, Science, 291, 1031-1036, 2001.

Liu, G., Tarasick, D. W., Fioletov, V. E., Sioris, C. E., and Rochon, Y. J.: Ozone correlation lengths and measurement uncertainties from analysis of historical ozonesonde data in
North America and Europe, J. Geophys. Res., 114, D04112, doi:10.1029/2008JD010576, 2009.

Liu, G., Liu, J., Tarasick, D. W., Fioletov, V. E., Jin, J. J., Moeini, O., Liu, X., Sioris, C. E., and Osman, M.: A global tropospheric ozone climatology from trajectory-mapped ozone soundings, Atmos. Chem. Phys., 13, 10659-10675, doi:10.5194/acp13-10659-2013, 2013.

Liu, H., Jacob, D. J., Bey, I., Yantosca, R. M., Duncan, B. N., and Sachse, G. W.: Transport pathways for Asian combustion outflow over the Pacific: Interannual and seasonal variations, J. Geophys. Res., 108, 8786, doi:10.1029/2002JD003102, 2003.

Liu, J., Drummond, J. R., Jones, D. B. A., Cao, Z., Bremer, H., Kar, J., Zou, J., Nichitiu, F., and Gille, J. C.: Large horizontal gradients in atmospheric $\mathrm{CO}$ at the synoptic scale as seen by spaceborne Measurements of Pollution in the Troposphere, J. Geophys. Res., 111, D02306, doi:10.1029/2005JD006076, 2006.

Liu, J., Tarasick, D. W., Fioletov, V. E., McLinden, C., Zhao, T., Gong, S., Sioris, C., Jin, J. J., Liu, G., and Moeini, O.: A global ozone climatology from ozone soundings via trajectory mapping: a stratospheric perspective, Atmos. Chem. Phys., 13, 1144111464, doi:10.5194/acp-13-11441-2013, 2013.

Logan, J. A., Prather, M. J., Wofsy, S. C., and McElroy, M. B.: Tropospheric chemistry: A global perspective, J. Geophys. Res., 86, 7210-7254, 1981.

Luo, M., Rinsland, C. P., Rodgers, C. D., Logan, J. A., Worden, H., Kulawik, S., Eldering, A., Goldman, A., Shephard, M. W., Gunson, M., and Lampel, M.: Comparison of carbon monoxide measurements by TES and MOPITT: Influence of a priori data and instrument characteristics on nadir atmospheric species retrievals, J. Geophys. Res., 112, D09303, doi:10.1029/2006JD007663, 2007.

Marenco, A., Thouret, V., Nedelec, P., Smit, H., Helten, M., Kley, D., Karcher, F., Simon, P., Law, K., Pyle, J., Poschmann, G., Wrede, R. V., Hume, C., and Cook, T.: Measurements of ozone and water vapour by Airbus in-service aircraft: The MOZAIC airborne program, An overview, J. Geophys. Res., 103, 2563125642, 1998.

McKee, D. J. (Ed.): Tropospheric Ozone: Human Health and Agricultural Impacts, Boca Raton, Fla., Lewis Publishers, 39-208, 1993.

Nedelec, P., Cammas, J.-P., Thouret, V., Athier, G., Cousin, J.-M., Legrand, C., Abonnel, C., Lecoeur, F., Cayez, G., and Marizy, C.: An improved infrared carbon monoxide analyser for routine measurements aboard commercial Airbus aircraft: technical validation and first scientific results of the MOZAIC III programme, Atmos. Chem. Phys., 3, 1551-1564, doi:10.5194/acp-3-15512003, 2003.

Nédélec, P., Thouret, V., Brioude, J., Sauvage, B., Cammas, J.P., and Stohl, A.: Extreme CO concentrations in the upper troposphere over North-East Asia in June 2003 from the insitu MOZAIC aircraft data, Geophys. Res. Lett., 32, L14807, doi:10.1029/2005GL023141, 2005.

Nédélec, P., Blot, R., Boulanger, D., Athier, G., Cousin, J.-M., Gautron, B., Petzold, A., Volz-Thomas, A., and Thouret, V.: Instrumentation on commercial aircraft for monitoring the atmospheric composition on a global scale: the IAGOS system, technical overview of ozone and carbon monoxide measurements, Tellus B, 67, 27791, doi:10.3402/tellusb.v67.27791, 2015. 
Novelli, P. C., Steele, L. P., and Tans, P. P.: Mixing ratios of carbon monoxide in the troposphere, J. Geophys. Res., 97, 2073120750, 1992.

Novelli, P. C., Masarie, K. A., Tans, P. P., and Lang, P. M.: Recent changes in atmospheric carbon monoxide, Science, 263, 15871590, 1994.

Novelli, P. C., Masarie, K. A., and Lang, P. M.: Distributions and recent changes of carbon monoxide in the lower troposphere, $\mathrm{J}$. Geophys. Res., 103, 19015-19033, 1998.

Novelli, P. C., Masarie, K. A., Lang, P. M., Hall, B. D., Myers, R. C., and Elkins, J. W.: Reanalysis of tropospheric CO trends: Effects of the 1997-1998 wildfires, J. Geophys. Res., 108, 4464, doi:10.1029/2002JD003031, 2003.

Parrish, D. D., Trainer, M., Holloway, J. S., Yee, J. E., Warshawsky, M. S., Fehsenfeld, F. C., Forbes, G. L., and Moody, J. L.: Relationships between ozone and carbon monoxide at surface sites in the North Atlantic region, J. Geophys. Res., 103, 13357-13376, 1998.

Parrish, D. D., Trainer, M., Buhr, M. P., Watkins, B. A., and Fehsenfeld, F. C.: Carbon monoxide concentrations and their relation to concentrations of total reactive oxidized nitrogen at two rural U.S. sites, J. Geophys. Res., 96, 9309-9320, 1991.

Petetin, H., Thouret, V., Fontaine, A., Sauvage, B., Athier, G., Blot, R., Boulanger, D., Cousin, J.-M., and Nedelec, P.: Characterizing tropospheric ozone and CO around Frankfurt between 19942012 based on MOZAIC-IAGOS aircraft measurements, Atmos. Chem. Phys. Discuss., 15, 23841-23891, doi:10.5194/acpd-1523841-2015, 2015

Petzold, A., Thouret, V., Gerbig, C., Zahn, A., Brenninkmeijer, C. A. M., Gallagher, M., Hermann, M., Pontaud, M., Ziereis, H., Boulanger, D., Marshall, J., Nédélec, P., Smit, H. G. J., Frieß, U., Flaud, J.-M., Wahner, A., Cammas, J.-P., Volz-Thomas, A., and IAGOS Team: Global-scale atmosphere monitoring by inservice aircraft - current achievements and future prospects of the European research infrastructure IAGOS, Tellus B, 67, 28452, doi:10.3402/tellusb.v67.28452, 2015

Ploeger, F., Konopka, P., Günther, G., Grooß, J.-U., and Müller, R.: Impact of the vertical velocity scheme on modeling transport across the tropical tropopause layer, J. Geophys. Res., 115, D03301, doi:10.1029/2009JD012023, 2010.

Ploeger, F., Konopka, P., Müller, R., Günther, G., Grooß, J.-U., Schiller, C., Ravegnani, F., Ulanovski, A., and Riese, M.: Backtrajectory reconstruction of water vapour and ozone in-situ observations in the TTL, Meteorol. Z., 21, 239-244, 2012.

Pommrich, R., Müller, R., Grooß, J.-U., Konopka, P., Ploeger, F., Vogel, B., Tao, M., Hoppe, C. M., Günther, G., Spelten, N., Hoffmann, L., Pumphrey, H.-C., Viciani, S., D’Amato, F., Volk, C. M., Hoor, P., Schlager, H., and Riese, M.: Tropical troposphere to stratosphere transport of carbon monoxide and long-lived trace species in the Chemical Lagrangian Model of the Stratosphere (CLaMS), Geosci. Model Dev., 7, 2895-2916, doi:10.5194/gmd7-2895-2014, 2014.

Reichle Jr., H. G., Connors, V. S., Holland, J. A., Sherrill, R. T., Wallio, H. A., Casas, J. C., Condon, E. P., Gormsen, B. B., and Seiler, W.: The distribution of middle tropospheric carbon monoxide during early October 1984, J. Geophys. Res., 95, 9845-9856, 1990.

Reichle Jr., H. G., Anderson, B. E., Connors, V. S., Denkins, T. C., Forbes, D. A., Gormsen, B. B., Langenfelds, R. L., Neil, D. O.,
Nolf, S. R., Novelli, P. C., Pougatchev, N. S., Roell, M. M., and Steele, L. P.: Space shuttle based global CO measurements during April and October 1994, MAPS instrument, data reduction, and data validation, J. Geophys. Res., 104, 21443-21454, 1999.

Rinsland, C. P. and Levine, J. S.: Free tropospheric carbon monoxide concentrations in 1950 and 1951 deduced from infrared total column amount measurements, Nature, 318, 250-254, 1985.

Rinsland, C. P., Jones, N. B., Connor, B. J., Wood, S. W., Goldman, A., Stephen, T. M., Murcray, F. J., Chiou, L. S., Zander, R., and Mahieu, E., Multiyear infrared solar spectroscopic measurements of $\mathrm{HCN}, \mathrm{CO}, \mathrm{C}_{2} \mathrm{H}_{6}$, and $\mathrm{C} 2 \mathrm{H} 2$ tropospheric columns above Lauder, New Zealand (45 S Latitude), J. Geophys. Res., 107, 4185, doi:10.1029/2001JD001150, 2002.

Rodgers, C. D.: Inverse Methods for Atmospheric Sounding: Theory and Practice, World Sci., Hackensack, N. J., 2000.

Sauvage, B., Thouret, V., Cammas, J.-P., Gheusi, F., Athier, G., and Nédélec, P.: Tropospheric ozone over Equatorial Africa: regional aspects from the MOZAIC data, Atmos. Chem. Phys., 5, 311335, doi:10.5194/acp-5-311-2005, 2005.

Sauvage, B., Gheusi, F., Thouret, V., Cammas, J.-P., Duron, J., Escobar, J., Mari, C., Mascart, P., and Pont, V.: Medium-range midtropospheric transport of ozone and precursors over Africa: two numerical case studies in dry and wet seasons, Atmos. Chem. Phys., 7, 5357-5370, doi:10.5194/acp-7-5357-2007, 2007.

Schoeberl, M. R., Douglass, A. R., Zhu, Z. X., and Pawson, S.: A comparison of the lower stratospheric age spectra derived from a general circulation model and two data assimilation systems, J. Geophys. Res., 108, 4113, doi:10.1029/2002JD002652, 2003.

Shindell, D. T., Faluvegi, G., Stevenson, D. S., Krol, M. C., Emmons, L. K., Lamarque, J.-F., Pétron, G., Dentener, F. J., Ellingsen, K., Schultz, M. G., Wild, O., Amann, M., Atherton, C. S., Bergmann, D. J., Bey, I., Butler, T., Cofala, J., Collins, W. J., Derwent, R. G., Doherty, R. M., Drevet, J., Eskes, H. J., Fiore, A. M., Gauss, M., Hauglustaine, D. A., Horowitz, L. W., Isaksen, I. S. A., Lawrence, M. G., Montanaro, V., Müller, J.-F., Pitari, G., Prather, M. J., Pyle, J. A., Rast, S., Rodriguez, J. M., Sanderson, M. G., Savage, N. H., Strahan, S. E., Sudo, K., Szopa, S., Unger, N., van Noije, T. P. C., and Zeng, G.: Multi-model simulations of carbon monoxide: Comparison with observations and projected near-future changes, J. Geophys. Res., 111, D19306, doi:10.1029/2006JD007100, 2006.

Stein, O., Schultz, M. G., Bouarar, I., Clark, H., Huijnen, V., Gaudel, A., George, M., and Clerbaux, C.: On the wintertime low bias of Northern Hemisphere carbon monoxide found in global model simulations, Atmos. Chem. Phys., 14, 9295-9316, doi:10.5194/acp-14-9295-2014, 2014.

Stohl, A.: Computation, accuracy and applications of trajectories review and bibliography, Atmos. Environ. 32, 947-966, 1998.

Stohl, A. and Seibert, P.: Accuracy of trajectories as determined from the conservation of meteorological tracers, Q. J. Roy. Meteor. Soc., 125, 1465-1484, 1998.

Stohl, A., James, P., Forster, C., and Spichtinger, N.: An extension of Measurement of Ozone and Water Vapour by Airbus-In-service aircraft (MOZAIC) ozone climatologies using trajectory statistics, J. Geophys. Res., 106, 27757-27768, doi:10.1029/2001JD000749, 2001.

Tan, Q., Chameides, W. L., Streets, D., Wang, T., Xu, J., Bergin, M., and Woo, J.: An evaluation of TRACE-P emission inventories from China using a regional model and chemical measurements, 
J. Geophys. Res., 109, D22305, doi:10.1029/2004JD005071, 2004.

Tarasick, D. W., Jin, J. J., Fioletov, V. E., Liu, G., Tompson, A. M., Oltmans, S. J., Liu, J., Sioris, C. E., Liu, X., Cooper, O. R., Dann, T., and Thouret, V.: High-resolution tropospheric ozone fields for INTEX and ARCTAS from IONS ozonesondes, J. Geophys. Res., 115, D20301, doi:10.1029/2009JD012918, 2010.

Thompson, A. M.: The oxidizing capacity of the Earth's atmosphere-Probable past and future changes, Science, 256, 1157-1165, doi:10.1126/science.256.5060.1157, 1992.

Tie, X., Brasseur, G. P., Zhao, C., Granier, C., Massie, S., Qin, Y., Wang, P., Wang, G., Yang, P., and Richterg, A.: Chemical characterization of air pollution in eastern China and the eastern United States, Atmos. Environ., 40, 2607-2625, 2006.

Volz-Thomas, A., Berg, M., Heil, T., Houben, N., Lerner, A., Petrick, W., Raak, D., and Pätz, H.-W.: Measurements of total odd nitrogen $\left(\mathrm{NO}_{y}\right)$ aboard MOZAIC in-service aircraft: instrument design, operation and performance, Atmos. Chem. Phys., 5, 583595, doi:10.5194/acp-5-583-2005, 2005.

Wang, T., Carroll, M. A., Alber, G. M., Owens, K. R., Duderstadt, K. A., Markevitch, A., Parrish, D., Holloway, J., Fehsenfeld, F. C., Forbes, G., and Ogren, J.: Ground-based measurements of NOx and total reactive oxidized Nitrogen $\left(\mathrm{NO}_{y}\right)$ at Sable Island, Nova Scotia during the NARE 1993 Summer Intensive, J. Geophys. Res., 101, 28991-29004, 1996.

Wang, T., Lam, K. S., Chan, L. Y., Carroll, M. A., and Lee, A. S. Y.: Trace gas measurements in coastal Hong Kong during the PEMWEST (B), J. Geophys. Res., 102, 28575-28588, 1997.

Wang, Y. X., McElroy, M. B., Wang, T., and Palmer, P. I.: Asian emissions of $\mathrm{CO}$ and NOx: Constraints from aircraft and Chinese station data, J. Geophys. Res., 109, D24304, doi:10.1029/2004JD005250, 2004.
WHO: Air quality guidelines for Europe, Copenhagen, World Health Organization Regional Office for Europe, 2000 (WHO Regional Publications, European Series No. 91), 2nd Edn., 2000.

Worden, H. M., Deeter, M. N., Edwards, D. P., Gille, J. C., Drummond, J. R., and Nedélec, P. P.: Observations of near-surface carbon monoxide from space using MOPITT multispectral retrievals, J. Geophys. Res., 115, D18314, doi:10.1029/2010JD014242, 2010.

Worden, H. M., Deeter, M. N., Frankenberg, C., George, M., Nichitiu, F., Worden, J., Aben, I., Bowman, K. W., Clerbaux, C., Coheur, P. F., de Laat, A. T. J., Detweiler, R., Drummond, J. R., Edwards, D. P., Gille, J. C., Hurtmans, D., Luo, M., MartínezAlonso, S., Massie, S., Pfister, G., and Warner, J. X.: Decadal record of satellite carbon monoxide observations, Atmos. Chem. Phys., 13, 837-850, doi:10.5194/acp-13-837-2013, 2013.

Yurganov, L. N., McMillan, W., Dzhola, A. V., Grechko, E. I., Jones, N. B., and van der Werf, G. R.: Global AIRS and MOPITT CO measurements: validation, comparison, and links to biomass burning variations and carbon cycle, J. Geophys. Res., 113, 1-14, 2008.

Zander, R., Demoulin, P., Ehhalt, D. H., Schmidt, U., and Rinsland, C. P.: Secular increase of the total vertical column abundance of carbon monoxide above central Europe since 1950, J. Geophys. Res., 94, 11021-11028, 1989.

Zbinden, R. M., Thouret, V., Ricaud, P., Carminati, F., Cammas, J.P., and Nédélec, P.: Climatology of pure tropospheric profiles and column contents of ozone and carbon monoxide using MOZAIC in the mid-northern latitudes $\left(24^{\circ} \mathrm{N}\right.$ to $\left.50^{\circ} \mathrm{N}\right)$ from 1994 to 2009, Atmos. Chem. Phys., 13, 12363-12388, doi:10.5194/acp13-12363-2013, 2013. 